\title{
Finanças Comportamentais no Brasil
}

\author{
Daniel Yabe Milanez
}

"Actions are constrained by income, time, imperfect memory, calculating capacities, and other limited resources" ... "My work may have sometimes assumed too much rationality".

Gary Becker (1993)

\section{RESUMO}

Finanças Comportamentais são um programa de pesquisa que vem ganhando crescente reconhecimento no mundo acadêmico e fora dele. Seu traço distintivo é a incorporação de conceitos de outras áreas (como Psicologia e Sociologia) à Economia para explicar as decisões financeiras dos indivíduos.

Este trabalho pretende analisar os avanços recentes deste novo campo de pesquisa e verificar em que medida essa linha de pesquisa pode trazer contribuições para um melhor entendimento do comportamento do mercado financeiro brasileiro, uma vez que ainda é escassa a literatura nacional a esse respeito.

A primeira etapa consiste em caracterizar os principais conceitos das Finanças Comportamentais, mostrando em que aspectos aqueles diferem da hipótese de mercados eficientes.

O segundo passo será mostrar que as evidências encontradas em outros países também são verificadas no mercado financeiro brasileiro. Para tanto, serão realizados estudos empíricos com dados do mercado local, mediante técnicas que já foram utilizadas para testar essas "anomalias" no mercado internacional.

Por fim, pretende-se derivar dos avanços recentes na teoria de Finanças Comportamentais possíveis implicações sobre políticas econômicas, considerando como esses estudos podem ser relevantes para um melhor sistema de regulação e supervisão do mercado financeiro nacional. 


\section{Índice}

1) MERCADOS EFICIENTES, “ANOMALIAS” E FINANCAS COMPORTAMENTAIS .............................3

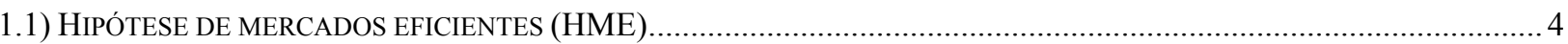

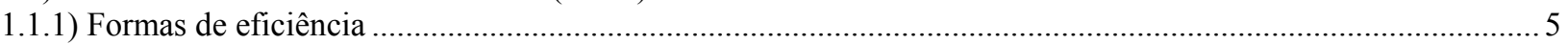

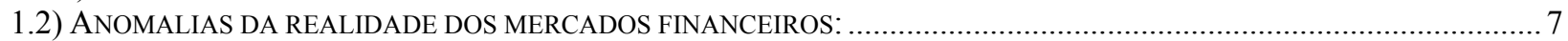

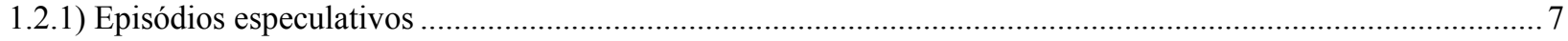

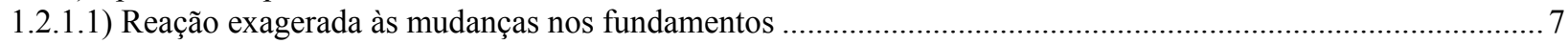

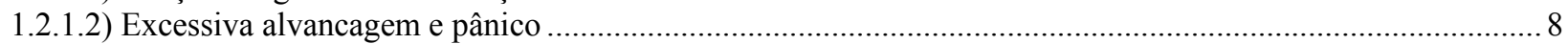

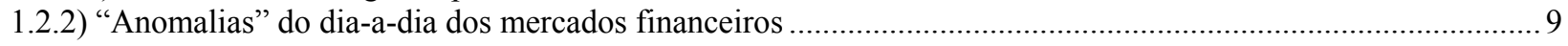

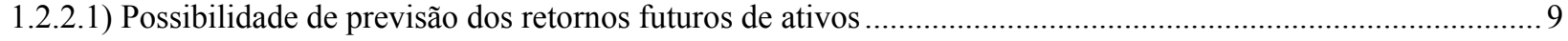

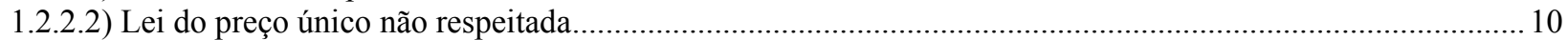

1.2.2.3) Volatilidade e preços com relação aos fundamentos............................................................................. 11

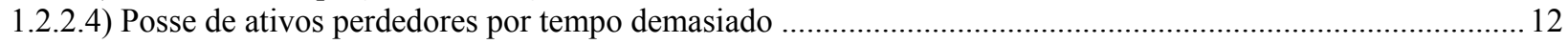

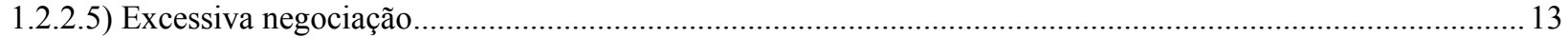

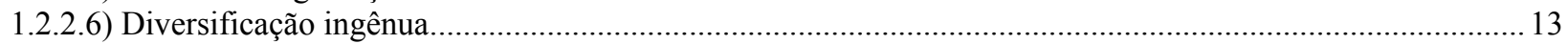

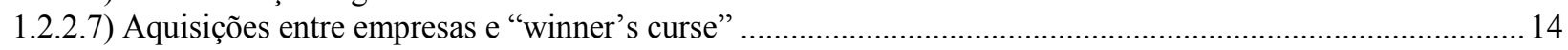

1.3) FINANÇAS COMPORTAMENTAIS E OS FUNDAMENTOS DO COMPORTAMENTO NÃO-RACIONAL .............................. 15

1.3.1) Surgimento da behavioral economics e da behavioral finance ................................................................ 15

1.3.2) Fundamentos do comportamento não racional: Psicologia e Economia ..................................................... 17

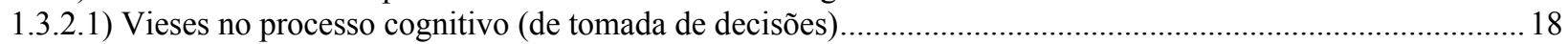

1.3.2.1.1) Regras de bolso viesadas (heuristic driven bias): ............................................................................ 19

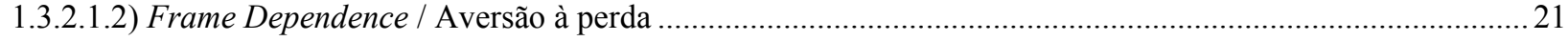

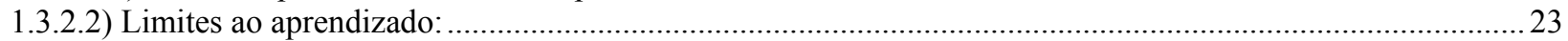

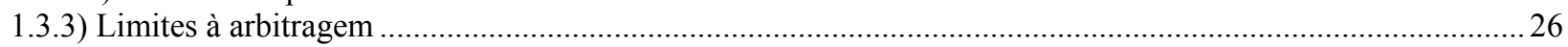

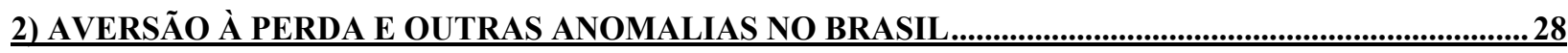

2.1) BASE DE DAdOS E METODOLOGIA PARA TESTAR AVERSÃO À PERDA ............................................................29

2.2) OUTROS ESTUdOS EMPÍRICOS SOBRE FINANÇAS COMPORTAMENTAIS NO MERCADO FINANCEIRO BRASILEIRO...... 32

\section{3) FINANCAS COMPORTAMENTAIS E GOVERNANCA PARA OS INVESTIDORES (INVESTOR}

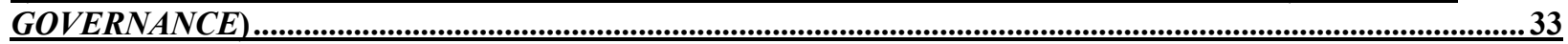

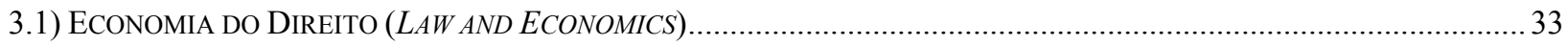

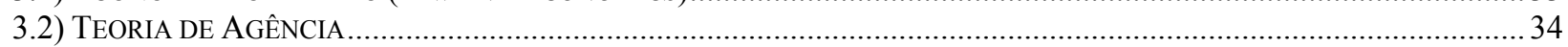

3.3) BEHAVIORAL FINANCE, LAW AND ECONOMICS E REGULAÇÃO DO MERCADO FINANCEIRO ....................................36

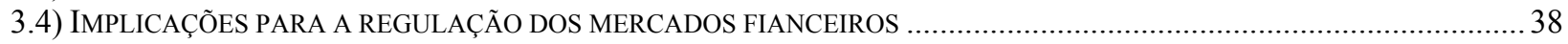

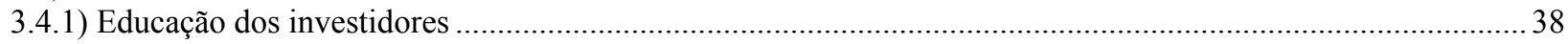

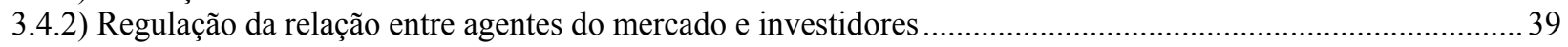

3.4.2.1) O viés inconsciente dos auditores e a provável ineficácia das leis propostas recentemente nos Estados

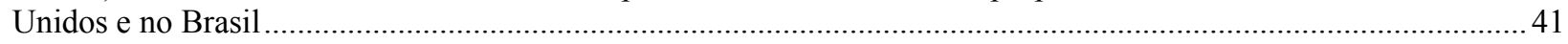

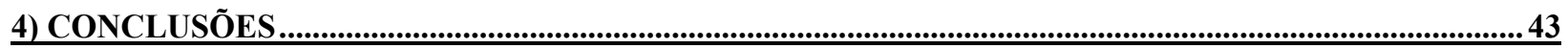

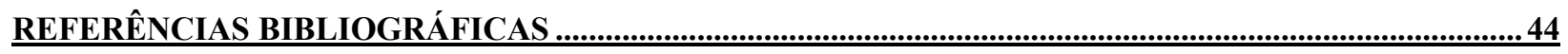

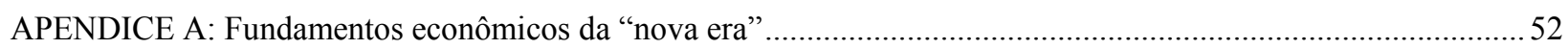

APENDICE B: O Encilhamento como primeiro episódio especulativo brasileiro................................................53 


\section{1) Mercados eficientes, "anomalias" e finanças comportamentais}

Teorias sobre comportamento humano importadas de outras áreas das ciências sociais têm ajudado a motivar muitos estudos sobre economia e finanças e atenção particular tem sido dedicada às implicações da chamada teoria de mercados eficientes em finanças. A tradição econômica neoclássica admite que cada indivíduo tem preferências estáveis e coerentes e maximiza racionalmente a utilidade proveniente dessas preferências. Nessa linha de raciocínio, a hipótese de mercados eficientes afirma que os preços incorporam de maneira eficiente todas as informações disponíveis e são a melhor estimativa do valor real dos ativos a que se referem.

Nas últimas duas décadas, os fundamentos que sustentam a hipótese de eficiência, como as operações de arbitragem (em que agentes se aproveitariam de distorções de preços executando operações que trariam novamente os preços para níveis racionais), mostraram-se mais limitadas do que se supunha quando passaram a surgir estudos com preços de ativos financeiros mostrando resultados adversos àqueles encontrados pelos criadores da hipótese de mercados eficientes.

Nesse contexto, a chamada Teoria de Finanças Comportamentais (behavioral finance) surge como uma opção à teoria de finanças tradicional. Sob esse novo prisma teórico, não se espera, por uma série de motivos comportamentais e de limites à arbitragem, que os mercados financeiros sejam eficientes. Mais do que isso, entende-se que desvios sistemáticos e significantes de preços com relação ao valor "fundamental" são normais (esperados) e podem perdurar por tempo indeterminado.

Mas por que estudar finanças comportamentais no Brasil, se nosso mercado financeiro (ou de capitais) é menos evoluído que o de outros países em que as pesquisas sobre este tema têm sido numerosas? O fato de encontrar resultados parecidos com os do mercado norteamericano no mercado brasileiro é importante porque um dos ataques aos testes de behavioral finance se refere à falta de generalidade, o que certamente deixa de ser verdade quando os resultados passam a ser encontrados em mercados e períodos diversos aos dos testes realizados sobre "anomalias" nos mercados financeiros.

Um melhor entendimento da precificação de ativos financeiros é um importante fim em si mesmo assim como potencialmente uma atividade lucrativa. Mas a pesquisa sobre isso leva a caminhos certamente mais importantes do ponto de vista econômico, como por exemplo entender as reais conseqüências da precificação "incorreta" para os mercados financeiros e para o sistema econômico em geral. A necessidade de maior compreensão dos mercados financeiros, cujo bom funcionamento é vital para o desenvolvimento econômico (Levine, 1997) e para a geração de possíveis contribuições que podem oferecer ao desenho da política econômica e dos arranjos institucionais uma perspectiva mais realista do funcionamento desses mercados.

Além disso, é importante notar a atualidade do tema, que se manifesta pelo fato de que nos últimos anos tem sido crescente a produção acadêmica nesta área nos Estados Unidos e em países europeus. Esta nova abordagem vem tendo ampla aceitação mesmo entre autores e escolas tradicionalmente adeptos de princípios econômicos neoclássicos (Thaler, 1993). A despeito disso, é ainda incipiente no Brasil a produção acadêmica nesta nova linha de pesquisa em finanças ${ }^{2}$.

\footnotetext{
${ }^{1}$ Nesse contexto, entende-se que um preço eficiente é aquele que reflete as informações (fundamentos econômicos) disponíveis aos agentes.

${ }^{2}$ A literatura se restringe a alguns trabalhos sobre anomalias nos mercados financeiros brasileiros (Costa Jr et al, 2001) e há alguns poucos artigos de revisão da literatura, como Halfeld (2001). Ver também Milanez (2001a): sobre vieses no processo cognitivo e seus efeitos sobre modelos de salário eficiência e sobre anomalias no comportamento
} 


\section{1) Hipótese de mercados eficientes (HME)}

"Efficient Market Hypothesis is the best established fact in all the social sciences". Michael Jensen ${ }^{3}$

A idéia por trás da expressão "hipótese de mercados eficientes" (HME), cunhada por Harry Roberts ${ }^{4}$, tem história muito maior do que se pensa nas pesquisas em finanças. A hipótese, sem o termo HME, aparece pela primeira vez num trabalho de Gibson ${ }^{5}$ em 1889 , ao mesmo tempo em que já eram conhecidos relatos sobre o comportamento humano não perfeitamente racional, como a obra de Mackay, de $1841^{6}$, sobre os episódios especulativos dos séculos XVII, XVIII e XIX. A teoria de mercados eficientes é baseada nas noções sobre um comportamento humano racional, maximizador de utilidades esperadas e apto a processar de maneira ótima todas as informações disponíveis. Neste sentido, pode-se dizer que os mercados são operados por agentes representativos que atuam sob racionalidade ilimitada, tomando decisões de acordo com a teoria da utilidade esperada, formando expectativas não-viesadas sobre eventos futuros.

Essa teoria pressupõe que haja: 1) competição perfeita: um suficiente número de participantes, o que implica que nenhuma ação individual pode afetar significativamente os preços; 2) expectativas homogêneas e racionalidade: os traders são totalmente informados, têm acesso igualitário aos mercados e agem racionalmente; e 3) ausência de fricções: os ativos ou commodities são homogêneos, divisíveis e não há custos transacionais. Até a década de 60, acreditava-se que as expectativas eram formadas com base em experiências passadas (expectativas adaptativas). Mas com os trabalhos de John Muth (1961), surge a chamada teoria de expectativas racionais: as pessoas utilizam todas as informações disponíveis (e não só eventos passados) e suas previsões serão ótimas (as melhores possíveis, não necessariamente precisas). Sob essas condições, os modelos de mercado perfeito implicariam precisamente os mesmos resultados que o modelo de passeio aleatório (random walk model) prevê: padrões passados de preços não são determinantes dos preços futuros, uma vez que as mudanças de preços não são dependentes nem correlacionadas com as mudanças passadas de preços.

A junção das pressuposições acima descritas com a de passeio aleatório forma a base do artigo de Fama (1970), em que o autor propõe que nenhuma informação (como preços passados ou notícias públicas) poderia trazer vantagens a determinado investidor porque tal dado seria instantaneamente refletido no preço do ativo a que ele estivesse relacionado. As implicações, de maneira geral, seriam que: 1) existe grande número de agentes maximizadores de utilidade operando nos mercados independentemente uns dos outros; 2) todos os agentes econômicos rapidamente ajustariam suas ofertas para refletir novas informações relacionadas aos ativos que estão transacionando; e 3) novas informações chegam ao mercado de maneira randômica e são independentes de outros conjuntos de informações disponíveis. Tal racionalidade, porém, não precisaria abranger todos os participantes do mercado. Ao mesmo tempo em que investidores não plenamente racionais (noise traders) estivessem operando, haveria smart traders (arbitradores racionais) que rapidamente operariam de maneira a auferir lucro com um eventual desvio dos preços com relação a seus fundamentos. Essa ação traria os preços novamente para o valor fundamental.

\footnotetext{
dos preços no mercado de câmbio; e Milanez (2001b), sobre a presença, de 1993 a 2001, de retornos extraordinários às sextas-feiras com relação às segundas-feiras para o Ibovespa e outras quatro ações de grande liquidez no mercado acionário brasileiro.

${ }^{3}$ Em seu discurso de recebimento do Prêmio Nobel, citado em Cunningham (1994).

${ }^{4}$ Segundo Shiller (1999), o artigo de Harry Roberts (1967) nunca foi publicado, e a fama por utilizar primeiramente a expressão foi dada a Eugene Fama, da Universidade de Chicago.

${ }^{5}$ Gibbson (1889), citado por Shiller (1999).

${ }^{6}$ As obras de Mackay e De La Vega foram reimpressas várias vezes, sendo uma das últimas edições Mackay e De la Vega (1996).
} 
Além disso, de acordo com Friedman (1953), investidores não poderiam perder dinheiro para sempre, uma vez que cada vez menos teriam dinheiro para fazer investimentos e seriam, no limite, excluídos do sistema. Isso não significa que não haveria possibilidade de ganhos no mercado de ações, por exemplo, mas significa que nenhum investidor conseguiria retornos anormais (superiores ao retorno ajustado ao risco envolvido em determinada ação ${ }^{7}$ ). Assim, os preços nos mercados financeiros incorporariam todas as informações disponíveis e seriam simultaneamente as melhores estimativas do valor fundamental dos ativos negociados. Além disso, os desvios de curto prazo refletiriam apenas pequenas mudanças nos padrões de oferta e demanda e deveriam ser considerados randômicos e, portanto, imprevisíveis.

Argumenta-se que o pressuposto da racionalidade ilimitada seria ainda mais apropriado para os mercados financeiros, uma vez que nestes operam profissionais que têm grandes incentivos para tomar decisões racionais em um ambiente em que informações se disseminam rapidamente a baixos custos. Os primeiros estudos neste sentido foram realizados por autores preocupados em analisar o comportamento de preços. O primeiro deles, o matemático francês Louis Bachelier, chegou à conclusão de que os preços de contratos de opções e futuros na Bolsa de Paris no início do século XX se comportavam de acordo com o modelo de passeio aleatório, segundo o qual preços passados não indicam de maneira alguma os preços futuros. Apesar de "esquecido" pelos economistas por cerca de meio século, tal trabalho, trazido à tona novamente por Samuelson (1965), torna-se a primeira prova de que preços se comportam de maneira aleatória, o que é um dos fundamentos principais da HME.

\subsection{1) Formas de eficiência}

Três formas de eficiência foram propostas por Fama (1970) para classificar os testes empíricos, dados os tipos de informações especificadas:

1. Axioma fraco: tem como base o modelo de passeio aleatório em si. Os erros de previsão podem acontecer e até mesmo ser grandes. Tais erros, porém, como se comportam de maneira aleatória, por definição têm média zero. Sob esse ponto de vista, nenhum investidor poderia obter retornos em excesso mediante a análise de preços passados, ou seja, as informações contidas nos preços passados não seriam relevantes para se obter um retorno em excesso àquele já ajustado ao risco de determinado ativo.

2. Axioma semiforte: investiga se todas as informações públicas (preços passados e outras) são refletidas no nível atual de preços. Assim, nenhum investidor poderia obter retorno em excesso fazendo operações baseadas nas análises de relatórios anuais de empresas, notícias publicadas ou outras fontes públicas de informação.

3. Axioma forte: todos os preços refletem os fundamentos do mercado (informações públicas e não-públicas) e estão corretos, ou seja, são sempre iguais a seu valor intrínseco. Aqui mesmo insider traders não poderiam obter retorno em excesso utilizando informações privilegiadas.

\footnotetext{
${ }^{7}$ Risco seria ajustado na hipótese de mercados eficientes pelo conhecido CAPM (Capital Asset Pricing Model). ${ }^{8}$ Segundo Cunningham (1994), talvez o trabalho de Bachelier tenha sido ofuscado por trabalhos sobre "passeios aleatórios" feitos em outras áreas (como os do botânico Robert Brown, que inspirou o trabalho de Albert Einstein sobre comportamento randômico das moléculas - conhecido como movimento browniano -, cujo modelo é o mesmo que Bachelier usou para descrever o movimento dos preços).
} 
Em virtude de a forma forte não possuir muito crédito mesmo entre os economistas defensores da HME, o debate se concentra entre as formas fraca (análise da validade no random walk model) e semi-forte (estudos sobre retornos anormais com base em informações públicas). Recentemente, o debate sobre a forma semiforte migrou para a chamada noise theory (distinção entre eficiência informacional e eficiência fundamental). Essa distinção diz respeito ao fato de que a eficiência informacional não implica que os preços atinjam a eficiência alocativa ou fundamental (preços são indicadores precisos do valor intrínseco dos ativos porque incorporam todas as informações relevantes relacionadas a eles), análise que primeiramente foi desenvolvida por James Tobin (1984).

De acordo com Tobin, a eficiência informacional apenas garante que nenhum investidor poderia obter retornos em excesso analisando as informações disponíveis publicamente. Apenas insiders poderiam auferir esse tipo de retorno, o que se relaciona com o axioma semiforte da HME. Não importa qual seja a informação disponível, esta já é automaticamente descontada no preço. A anedota a seguir ilustra bem essa idéia: Um professor de finanças e seu assistente estão caminhando pelo câmpus quando este faz uma pergunta: "Professor, estou vendo uma nota de vinte dólares no chão, devo pegá-la"? "Não, é claro que não, ela só pode ser falsa porque se não alguém já a teria pego", responde o professor.

Por outro lado, a eficiência fundamental se refere ao fato de os preços dos ativos nos mercados financeiros serem um perfeito indicador do valor intrínseco dos ativos, ou seja, refletiriam as expectativas racionais dos agentes a respeito dos pagamentos futuros (juros e dividendos, por exemplo) dos mesmos ativos. Essa distinção entre eficiência informacional e fundamental é relacionada com a metáfora do concurso de beleza formulada por Keynes: cada um julga a candidata pelo que acha que os outros julgam (um método não relacionado aos fundamentos) e não pelos fundamentos (méritos da candidata). É importante dizer que a influência da HME entre acadêmicos e praticantes de finanças, ainda é muito superior à força dos conceitos de finanças comportamentais, apesar dos vários exemplos que mostram que a realidade dos mercados financeiros está distante daquela proposta pela teoria de mercados eficientes. 


\section{2) Anomalias da realidade dos mercados financeiros:}

\subsection{1) Episódios especulativos}

"That the free-enterprise economy is given to recurrent episodes of speculation will be agreed. Thesegreat events and small, involving bank notes, securities, real estate, art, and other assets or objects - are, over the years and centuries, part of history".

John Kenneth Galbraith ${ }^{9}$

Kindleberger (1996), Mackay e De la Vega (1996), Chancellor (1999) e Galbraith (1996, 1997) demonstram que episódios especulativos históricos, como a "Tulipmania" na Holanda do século XVII e o crash de 1929 são dificilmente explicados por meio de mudanças drásticas nos fundamentos econômicos (Cutler et al, 1989). Keynes (1936) já dizia que: “... as flutuações diárias na lucratividade dos investimentos, que são obviamente de caráter efêmero e não significativas, tendem a ter uma influência excessiva e absurda no mercado". De acordo com o modelo de Hyman Minsky ${ }^{10}$ descrito por Kindleberger (1996), os episódios especulativos são inerentes ao próprio funcionamento do sistema financeiro. Tal análise é semelhante à feita por Galbraith (1993). Nesse modelo de Minsky, dá-se importância especial ao mercado de crédito, que, a partir do que o autor chama de displacement (alguma mudança nos fundamentos econômicos), funciona nesses episódios como verdadeiro catalisador do movimento de euforia mediante a alavancagem dos investidores, o que provoca, ao final do episódio, grande pânico entre os compradores que buscam vender seus ativos a qualquer preço.

Pode-se dividir a análise, de acordo com os modelos propostos por Kindleberger e Galbraith, em quatro grandes características presentes em todos episódios especulativos que provocaram graves crises econômico-financeiras ao redor do mundo nos últimos quatro séculos: 1) há algum tipo de mudança nos fundamentos econômicos que 2) provoca reação exagerada por parte dos agentes econômicos. Tal comportamento, catalisado por uma 3) excessiva alavancagem promovida durante o período de euforia leva o mercado a um inevitável 4) pânico.

\subsubsection{1) Reação exagerada às mudanças nos fundamentos}

De acordo com Shiller (2000a), um comportamento não perfeitamente racional já aparece nos primeiros momentos do episódio especulativo. As pessoas passam a ter a crença de que o futuro é mais promissor ou menos incerto do que o passado e passam a descrever o momento como uma "nova era". Tais pensamentos de otimismo exagerado, que surgem com o aparecimento de novos fundamentos, criam e reforçam o movimento eufórico de qualquer episódio especulativo. Aliás, investidores e jornalistas muitas vezes "inventam" um ambiente de "nova era" para justificar o próprio aumento espetacular de preços.

\footnotetext{
${ }^{9}$ Galbraith (1993).

${ }^{10}$ De acordo com Kindleberger (1996), outras análises sobre a fragilidade do sistema financeiro que se assemelham à de Minsky foram feitas por Irving Fisher, John Stuart Mill, Alfred Marshall e Knut Wicksell.
} 
De acordo com Galbraith (1993), em todos os eventos especulativos está presente a idéia de que há "algo novo" no mundo: as tulipas na Holanda no século XVII, as joint-stock companies no século XVIII com Jonh Law na França ou até mesmo a febre com as operações com junk bonds e estruturações de aquisições por meio de operações de leveraged-buyout que deram o tom do crash de 1987 nos EUA. ${ }^{11}$ É importante ressaltar que esse fundamento "novo" está ligado a um elemento de orgulho em virtude da descoberta da oportunidade de investimento ou do novo instrumento financeiro. A percepção de algo novo e excepcional, que por algum tempo também engorda os bolsos, gratifica o ego dos participantes do episódio. Exemplos de episódios ocorridos nos Estados Unidos, sem dúvida o país recordista em número de "especulações históricas", estão em apêndice ao final do trabalho.

\subsubsection{2) Excessiva alvancagem e pânico}

A característica final do período pré-crash de um episódio especulativo é a expansão, de alguma maneira, do crédito (Kindleberger, 1996). Por meio do sistema bancário existente, pela criação de novos bancos e de instrumentos de crédito ou mesmo pela expansão do crédito pessoal fora do sistema financeiro, a expansão dos meios de pagamento em movimentos de euforia se dá de maneira proporcional ao aumento rápido dos ativos alvos da especulação. Em 1928 e 1929, as taxas de juros cobradas em operações de crédito para compra de ações nos Estados Unidos chegaram a 15\%, padrão muito acima do normal para a época. Tais taxas eram utilizadas em financiamentos de compra de ações em que a margem necessária era de apenas $10 \%$. Aliás, tais operações de compra em margem eram consideradas à época como uma grande inovação do mercado financeiro e mais uma característica da "nova era".

A última fase de um episódio especulativo se caracteriza pelo sentimento de "extremo" pessimismo a respeito das condições que conduziram os preços ao movimento eufórico anterior. De acordo com o modelo de Minsky, alguns insiders com peso importante na condução da tendência de alta decidem desfazer suas posições de maneira drástica. Muitas razões são colocadas por observadores, quase sempre a posteriori, do que teria sido fator fundamental para precipitar a crise. Isso nada mais é do que a busca, segundo Galbraith (1993), de uma "racionalidade" para justificar as vendas em massa, em um ambiente que até pouco tempo era tomado por uma euforia que não poderia ser chamada de "racional".

A quebra de um banco ou de uma firma, a revelação de atos criminosos ligados ao frenesi especulativo ou simplesmente a abrupta queda do preço dos ativos por alguma razão são exemplos típicos do que se argumenta em momentos de pânico no mercado financeiro. Ao mesmo tempo, é muito difícil ouvir ou ler relatos de observadores ou participantes de um episódio especulativo a respeito das próprias fraquezas dos "fundamentos" que faziam os preços subir exageradamente até o momento do pânico. Apenas se culpa alguém ou algo pelo crash. Como diz Galbraith (1993): "A raiva será dirigida àqueles que haviam sido os mais admirados por sua imaginação e perspicácia financeira". Ao final deste trabalho outro apêndice mostra como pode ser considerado um episódio especualtivo o período conhecido na historiografia econômica brasileira como Encilhamento (1889-1891), em que houve um momento de extremo otimismo, refletido no movimento da Bolsa de Valores do Rio de Janeiro, seguido por uma séria crise econômico-financeira que se alastrou ao longo da última década do século XIX.

\footnotetext{
${ }^{11}$ Deve lembrar que alguns autores tentam explicar tais acontecimentos históricos com uma abordagem de expectativas racionais, como Garber (1989).
} 


\subsection{2) "Anomalias" do dia-a-dia dos mercados financeiros}

Estudos empíricos e experimentais realizados por equipes de diversas áreas (como psicólogos e economistas) têm mostrado que existem inúmeras situações em que o comportamento dos agentes nos mercados financeiros se desvia bastante da racionalidade suposta pela teoria neoclássica. Dois exemplos podem ser apontados:

1. Investidores dão valor exagerado às boas notícias sobre empresas cujas ações tiveram bom desempenho em passado recente e ignoram boas informações sobre as de desempenho recente ruim (De Bondt e Thaler, 1985). Tal situação é um exemplo claro de imperfeição e viés na coleta e armazenagem das informações pelos investidores.

2. Investidores nos mercados financeiros tendem a não aceitar perdas (loss aversion) relutando a se desfazer de posições em que tenham prejuízo enquanto liquidam rapidamente posições vencedoras (Ferris et al, 1988). O contexto em que o problema é apresentado e fatores psicológicos afetam a tomada de decisões.

Hishleifer (2001) e Shleifer (2001), entre outros autores, fornecem outros exemplos de racionalidade limitada nos mercados financeiros. A seguir são analisadas algumas delas.

\subsubsection{1) Possibilidade de previsão dos retornos futuros de ativos}

A teoria de mercados eficientes implica que preços seguem padrão aleatório de comportamento. Seria impossível prever o retorno futuro com base em preços passados. Entretanto, estudos como de Fama e French (1986) e Cutler, Poterba e Summers (1991), dentre muitos outros, porém, mostram significativa correlação entre os retornos diários (retornos positivos seguidos por retornos negativos). Mesmo defensores da HME, como seu "fundador", Fama, admitem que as ações são, ao menos parcialmente, sujeitas à previsibilidade de seus retornos, baseando-se a análise em retornos passados, relações de preço-lucro, preço-valor contábil, anúncios de lucros ou dividendos, programas de recompra de ações e ofertas sazonais de ações por empresas (Fama, 1991).

Um dos principais exemplos são as reações exageradas (overreaction) dos analistas e investidores com relação ao desempenho de ações que apresentem tendência de alta em detrimento daquelas que tenham tido baixo desempenho recente ${ }^{12}$, basicamente mostrando um processo de reversão de longo prazo nos retornos dos preços de ações. Ações cujo desempenho fícou muito acima da média do mercado tendem a piorar seus retornos nos períodos subseqüentes, acontecendo o contrário com aquelas que estavam com retorno abaixo da média (estas passam a ter retorno maior em períodos posteriores). Talvez o resultado mais importante nesta linha de "erros de expectativas" seja os de autores como Lakonishok et al (1993) e La Porta et al (1997), que mostram que as value stocks (menos valorizadas no último período) respondem normalmente aos anúncios de lucros e dão melhores retornos futuros comparativamente às growth stocks (de melhores retornos passados), que respondem negativamente ao anúncio de lucros.

Fama (1998) e outros autores, como Rubinstein (2000), procuram mostrar que tais resultados são eventos aleatórios (chance results), uma vez que aparentemente as reações exageradas (overreaction) são tão comuns quanto os underreactions. Segundo eles, se tais estudos fossem corretos, por que não existem oportunidades de retornos anormais de maneira consistente? Como vai ser observado mais adiante, o fato de existirem fenômenos não explicáveis pela teoria de mercados eficientes não implica que situações de free lunch surjam, pois existem os chamados limites à arbitragem.

\footnotetext{
${ }^{12} \mathrm{O}$ trabalho pioneiro analisando esse comportamento foi feito por De Bondt e Thaler (1985). Costa Jr. (1994) realizou o mesmo teste para o mercado brasileiro de ações.
} 


\subsubsection{2) Lei do preço único não respeitada}

Uma das evidências neste sentido é encontrada analisando-se os preços das cotas dos chamados closed-end funds, fundos cujo valor das cotas negociadas em Bolsa diverge do valor das ações que compõem a carteira dos fundos, mesmo quando se extraem custos de transação. De 1965 a 1985 o desconto médio ficou em 10,1\%. Descontos ou prêmios são normais, mas tais discrepâncias apresentam grande variabilidade ao longo do tempo e entre os diversos fundos.

Uma explicação "racional" considera que o desconto ou prêmio poderia refletir a capacidade dos gestores em gerar lucros futuros para o fundo. Mas estudos recentes não parecem apontar esse caminho, ou seja, o desempenho futuro é fracamente relacionado aos descontos atuais. Geralmente os IPOs (Initial Public Offering) dos closed-end funds são vendidos com prêmios. Em 1929 a média do prêmio desses fundos era $47 \%{ }^{13}$, e apenas no terceiro quadrimestre daquele ano foram captados $\$ 1,9 \mathrm{bi}^{14}$. Após o crash, os fundos passaram a ser vendidos normalmente com desconto, o que era impensável até 1929.

Uma das causas dos descontos deve ser o fato de que alguns fundos mantêm em carteira ações com pouca liquidez, o que complicaria um eventual desmanche dessas posições. Apesar disso, a grande maioria dos fundos vendidos com desconto não mantém posições relevantes em ações ilíquidas. Os fatos que demonstram a ocorrência de fenômenos não-explicáveis pela teoria de mercados eficientes não estão somente em episódios especulativos ou em características isoladas do mercado de capitais. Considere-se o caso do famoso Long Term Capital Management (LTCM), fundo que gerou retornos absolutos espetaculares entre 1994 e $1997^{15}$. Os três sócios que geriam a carteira eram os nada desconhecidos vencedores do prêmio Nobel Myron Scholes e Robert Merton que, juntos com John Meriwether, ${ }^{16}$ ao final de 97 administravam mais de US\$ 7 bilhões.

Em 1998, porém, o fundo foi socorrido por um grupo de bancos e investidores após acumular perdas de quase $50 \%$ em apenas 9 meses. Muitas das "apostas" certamente estavam erradas, mas uma particularmente ilustra a presença de "anomalias" ou fenômenos não explicáveis pela teoria de mercados eficientes. Segundo Shefrin (2000), o fundo tinha uma expressiva posição em duas ações - Royal Dutch Petroleum e Shell Transport and Trading -, que fizeram uma fusão no início do século XX na proporção de 60/40 entre as suas ações e criaram a Royal Dutch/Shell. As ações das duas empresas originárias ainda são negociadas em duas Bolsas distintas. ${ }^{17}$ Em teoria, o valor de mercado das ações da Royal Dutch deveria valer $50 \%$ mais do que o valor de mercado das ações da Shell.

\footnotetext{
${ }^{13}$ DeLong et al (1990).

${ }^{14}$ Ajustados para o ano de 1993, esse montante valeria $\$ 55$ bilhões, o que equivalia a cinco vezes o patrimônio desse tipo de fundo.

${ }^{15}$ O retorno médio anual do LTCM nesses quatro anos foi de $30,15 \%$ descontadas as taxas de administração e de performance.

${ }^{16} \mathrm{Um}$ dos pioneiros em operações de arbitragem com títulos de renda fixa no mercado financeiro,

${ }^{17}$ Royal Dutch Petroleum na London Stock Exchange e Shell transport and Trading na New York Stock Exchange.
} 
Entretanto, em um século de negociações, os preços dessas ações raramente respeitaram a proporção real, como mostram os estudos de Rosenthal e Young (1990) e Kenneth Froot e André Perold (1996). Ações da Shell são negociadas com um desconto não de 50\% mas sim de cerca de $20 \%$. Ao fazer operações que apostavam na diminuição dessa distorção, os gestores viram seus prejuízos aumentar dia após dia porque a "anomalia" aumentava constantemente. Possivelmente em uma decisão emocional, tais traders decidiram aumentar a aposta e assim alavancaram em demasia a posição do fundo nesse tipo de spread (comprado em determinada ação e vendido na outra), acarretando prejuízos enormes à carteira que administravam. A lição que fica deste caso é que, por mais que a relação entre dois preços seja fácil de ser estabelecida e calculada, os preços podem divergir, e os arbitradores são limitados em sua habilidade de restaurar os valores aos seus níveis "corretos".

\subsubsection{3) Volatilidade e preços com relação aos fundamentos}

Em um mundo em que os agentes são plenamente racionais, os preços só deveriam mudar com a chegada de novas informações. Entretanto, o que se nota na prática é que os preços (de ações ou de índices de ações, por exemplo) se movimentam e não podem ser atribuídos objetivamente a qualquer nova informação, uma vez que tais flutuações de preços tendem a ser grande demais para serem justificadas pelas novas informações que chegam ao conhecimento dos investidores (Shiller, 1981). Embora o trabalho de Shiller tenha gerado grande controvérsia, a maioria dos estudiosos do assunto admite que a volatilidade de títulos de renda fixa e de ações é maior do que aquela que um modelo de mercados eficientes prevê, como demonstram estudos que utilizam fundamentos econômicos (pagamentos de dividendos, PIB, M1, taxa de juros, spreads de títulos corporativos, índices de inflação, volatilidade do preço das ações) para justificar o movimentos dos índices de ações (Cutler et al, 1989).

Outros estudos têm mostrado que existe pouca ou nenhuma correlação entre a variabilidade dos preços em qualquer mercado e a chegada de novas informações relevantes. Roll (1984) observou que é muito difícil, por exemplo, explicar a volatilidade dos preços do suco de laranja (contratos futuros negociados na New York Futures Exchange) com base em notícias sobre o clima. O mesmo autor, em artigo de 1986, encontrou resultados similares ao analisar o movimento dos preços de ações e notícias a elas relacionadas. Trabalho semelhante já havia sido realizado por Niederhoffer (1971), que não encontrou correlação alguma (ou muito baixa) entre notícias importantes e mudanças nos preços de ações. Shiller (2000a) também conclui que as notícias mais importantes em dias de pânico (em 1929 e 1987) acabaram sendo as do próprio mercado de ações e não de seus fundamentos ${ }^{18}$. Mesmo as grandes variações diárias parecem ter pouco a ver com mudanças drásticas nos fundamentos, como mostram os exemplos da crise de 1987 a seguir, extraídos de Cutler et al (1989):

\begin{tabular}{|c|c|l|}
\hline Data & $\begin{array}{c}\text { Índice S\&P } \\
\mathbf{5 0 0}\end{array}$ & \multicolumn{1}{c|}{ "Explicações” do jornal New York Times } \\
\hline $16 / 10 / 1987$ & $-5,16 \%$ & Preocupações com déficit comercial, medo de altas nas taxas de juros, tensão com Irã. \\
\hline $19 / 10 / 1987$ & $-20,47 \%$ & Preocupação sobre a desvalorização do dólar e déficit comercial. \\
\hline $20 / 10 / 1987$ & $+5,33 \%$ & Investidores procurando ações de qualidade. \\
\hline $21 / 10 / 1987$ & $+9,10 \%$ & Taxas de juros continuam caindo, caça à barganhas. \\
\hline $26 / 10 / 1987$ & $-8,28 \%$ & Preocupações com déficit comercial, reações a quedas de ações em outros países. \\
\hline
\end{tabular}

\footnotetext{
${ }^{18}$ Segundo o autor, a mídia é um propagador fundamental dos movimentos dos preços, por meio de seus esforços para tornar as notícias "vendáveis".
} 
Outra anomalia dos mercados de opções são os diferenciais de volatilidade implícita (único fator não-observável na precificação de uma opção de compra ou de venda) entre opções de mesmas características com preços de exercício diferentes. Em teoria, tais volatilidades deveriam ser iguais porque se referem à volatilidade estimada para o mesmo ativo no mesmo período, mas não são. Geralmente, as opções de compra com preços de exercício menores (inthe-money) têm volatilidade implícita maior que as opções out-of-money. No Brasil, as opções de compra de Telemar PN, atualmente as mais negociadas na Bovespa, têm em média um diferencial de quase $20 \%$ de diferença entre as volatilidades implícitas das opções de compra com preço de exercício baixo e as de exercício alto. Se o preço do ativo está em $\mathrm{R} \$ 25,00$, as opções de compra com preço de exercício $\mathrm{R} \$ 20,00$ tendem a ter volatilidade implícita $20 \%$ maior que as opções de compra com preço de exercício de $\mathrm{R} \$ 30,00$. A volatilidade implícita é uma estimativa da volatilidade do preço do ativo até a data de vencimento e não deveria depender do preço de exercício de cada contrato de opção.

\subsubsection{4) Posse de ativos perdedores por tempo demasiado}

É uma experiência extremamente desgastante se desfazer de um ativo que se tenha comprado por preço mais alto do que está sendo vendido. Ao mesmo tempo em que vendem rapidamente os ativos em que obtêm lucro, investidores demoram muito a se desfazer daqueles em que têm prejuízo. Vários estudos mostram isso com investimentos em ações, fundos mútuos de investimento e imóveis. Odean (1998), utilizando dados de 163 mil contas de clientes de uma corretora de ações, mostrou que os investidores realizaram ganhos numa proporção $68 \%$ maior do que realizaram perdas. Isso significa que uma ação que tem retorno positivo tem cerca de $70 \%$ mais chances de ser vendida do que uma ação que tem desempenho negativo. Apenas no mês de dezembro, provavelmente por questões tributárias, não se encontrou diferença significativa entre as operações.

Estudo semelhante, segundo Shleifer (2000), foi feito por Heisler (1994) com contas de indivíduos que operaram contratos futuros de Treasury Bonds na Chicago Board of Trade no período entre 1989 e 1992. Tais especuladores também tinham grande tendência a segurar posições perdedoras por tempo muito maior do que ficavam posicionados em operações vencedoras. Pode-se dizer que por motivos de custos de transação, investidores teriam menor propensão a negociar as ações com menor valor (maior custo de corretagem proporcionalmente ao valor do investimento) (Rubinstein, 2000). Entretanto, existem inúmeras ocasiões em que ações com retorno negativo em períodos passados não são negociadas com altos custos proporcionais de transação. O exemplo de Nicholas Leeson - que em 1995, começou a fazer grandes especulações para diminuir os prejuízos que erros de sua equipe haviam causado em operações nas Bolsas asiáticas - talvez seja um dos melhores desse tipo de viés. Ao fazer isso, Leeson aumentou o prejuízo inicial para cerca de US\$ 1,4 bilhão, levando à falência seu empregador (o banco inglês Barings PLC, de 232 anos de história) (Shefrin, 2000). 


\subsubsection{5) Excessiva negociação}

De acordo com os modelos tradicionais, os participantes do mercado financeiro deveriam operar muito menos do que fazem de fato. A razão é que, em um mundo em que todos sabem que os outros são racionais, se alguém faz alguma oferta de compra por determinada ação e encontra um vendedor disposto a aceitar o preço, deveria desconfiar de que este último pode ter informações privilegiadas. Isso não quer dizer que não deveria haver negócios, porque investidores têm necessidade de rebalancear seus portfolios ou mesmo migrar para ativos de maior liquidez, mas simplesmente que os volumes encontrados nas principais Bolsas e nos mercados de câmbio certamente não refletem apenas demanda por diversificação de riscos ou busca por liquidez. O volume negociado em apenas um só dia nas transações de moedas no mercado à vista chega a 1,5 trilhão de dólares (cerca de $20 \%$ do PIB da maior economia do mundo). Nas Bolsas de Nova York e no pregão eletrônico Nasdaq o volume diário é de cerca de 15 bilhões de dólares.

Além disso, investidores tendem a negociar ações com altos betas, de empresas de pequeno porte que tiveram bons retornos em passado recente. Ao fazer isso, geralmente têm retorno médio bem abaixo do que se tivessem investido em um fundo que acompanhasse o desempenho de um índice de ações composto por ações dessa natureza (Barber e Odean, 1998b). A chegada das negociações via Internet, que reduziram consideravelmente os custos de negociação ${ }^{19}$, intensificou ainda mais essa tendência.

\subsubsection{6) Diversificação ingênua}

Richard Thaler e Shlomo Bernartzi têm escrito diversos artigos sobre o comportamento das pessoas ao alocarem seus recursos nos chamados fundos de pensão $401 \mathrm{k}$ nos Estados Unidos. Tais estudos mostram forte evidência de que as decisões de investimento nesse tipo de plano de aposentadoria não seguem qualquer padrão de diversificação de riscos que um modelo de escolha racional preveria para investimentos de longo prazo, como é o caso. De acordo com Shefrin (2000), o próprio Harry Markowitz, pai da chamada Teoria de Alocação Ótima de um portfolio de investimentos, disse que adota a regra de aplicar metade de seus recursos em títulos e outra metade em ações para diminuir o potencial de arrependimento futuro.

Em fundos de aposentadoria, os investidores tendem a fazer aplicações por meio do critério $1 / \mathrm{n}$ (chamada naive diversification) e não avaliam o risco e o potencial de retorno de suas aplicações com relação aos seus objetivos de longo prazo. Assim, se determinado plano oferece dois fundos de renda variável e um de renda fixa, as pessoas tendem a alocar um terço dos seus recursos em cada um deles, obtendo assim excessiva exposição ao risco de renda variável, como mostram Bernartzi e Thaler (1998) e Benartzi (2001).

\footnotetext{
${ }^{19}$ Entre 1996 e 1998, os custos de corretagem médios caíram cerca de 75\% nos Estados Unidos.
} 


\subsubsection{7) Aquisições entre empresas e "winner's curse"}

Por que algumas firmas pagam prêmios acima do preço de mercado para comprar outra? De acordo com Roll (1986), os acionistas da firma que está sendo vendida obtêm retornos posteriores ao anúncio da transação muito superiores aos dos acionistas da empresa compradora. Estudo da McKinsey mostram que em fusões amigáveis e leilões o desempenho posterior da ação do comprador é de, respectivamente, $2,5 \%$ e $4 \%$, enquanto o retorno para os acionistas das empresas vendidas é, respectivamente, de $30 \%$ e $35 \%$. A lógica por trás dessa aparente "maldição" dos compradores se relaciona ao fato de que, quando uma empresa se interessa por comprar outra (target), ela faz uma avaliação própria de quanto valeria uma eventual sinergia entre as duas empresas no caso de aquisição ser concretizada. Se tal avaliação resulta em preço inferior ao valor de mercado da empresa target, não se faz oferta alguma. Tal operação só é levada adiante se o preço da avaliação é superior ao valor de mercado. Esse tipo de negociação, porém, geralmente leva à maldição do vencedor porque normalmente as estimativas do valor da sinergia superam o que acontece de fato após a aquisição.

Existem dois tipos de winner's curse, de acordo com Thaler (1992). Uma empresa, ao avaliar o valor de uma sinergia ou de um projeto de investimento, faz isso de maneira exageradamente otimista. Assim, pode perder dinheiro por investir recursos em projetos que darão prejuízo futuro ou então podem perder ao pagar mais do que vale determinado negócio e, mesmo que este seja lucrativo, não trará o retorno que se imaginava quando se fez a oferta. Os mesmos resultados são encontrados em outros tipos de leilão, como para exploração de bacias petrolíferas. Thaler (1992) mostra que as diferenças entre as ofertas vencedoras e as perdedoras chegam a valores exorbitantes. No caso do Alaska, a diferença entre as ofertas vencedoras e as segundas melhores foi de $143 \%$. De acordo com estudos dos arrendamentos do Golfo do México (1954 a 1969), 62\% dos arrendamentos eram de áreas totalmente improdutivas do ponto de vista petrolífero, $16 \%$ tinham certo potencial produtivo mas deram resultado negativo e apenas $22 \%$ eram lucrativos e apresentaram lucratividade (após impostos) de 18,74\%.

Os casos brasileiros nas privatizações com envelopes fechados também ilustram bem esse exagero, e aqui provavelmente o chamado overbidding apareça com ainda mais força. Em leilões normais, os compradores podem observar as ofertas de seus concorrentes e assim podem pagar menos do que o valor máximo que estão dispostos a desembolsar por determinada empresa. Entretanto, no caso dos leilões com envelopes fechados os compradores não podem verificar quais são as ofertas dos concorrentes e provavelmente estarão mais propensos a fazer ofertas excessivamente altas, uma vez que terão grande receio de perder o leilão. No caso da compra do Banespa, o comprador (Santander) pagou cerca de quatro vezes mais que o valor da segunda melhor proposta (no mesmo dia as ações do Santander caíram na Bolsa de Madri o equivalente aos R\$ 4 bilhões que foram pagos acima da segunda maior oferta). 


\title{
1.3) Finanças Comportamentais e os fundamentos do comportamento não-racional
}

\author{
"In no field of empirical inquiry has so massive and sophisticated a statistical machinery been used with so \\ indifferent results".
}

Wassily Leontief ${ }^{20}$

\subsection{1) Surgimento da behavioral economics e da behavioral finance}

Críticas antigas à teoria de mercados eficientes, como os trabalhos de Herbert Simon sobre racionalidade limitada, ganharam reforço de pesquisadores de outras áreas (como Psicologia e Sociologia) nas últimas décadas, principalmente com a divulgação das pesquisas de Kahneman e Tversky no final da década de 70. Essa linha de pesquisa ganhou enorme audiência entre economistas, e hoje vários de seus mentores atuam nas principais escolas de Economia e Negócios dos Estados Unidos, como Robert Shiller (Yale), Richard Thaler (Chicago), David Laibson, Andrei Shleifer (Harvard) e James Poterba (MIT). Em várias delas existem cursos sobre behavioral economics, e as últimas edições do Journal of Finance contêm vários artigos dedicados a behavioral finance.

O recente Prêmio Nobel de Economia concedido a Daniel Kahneman por seus trabalhos em behavioral economics mostra que essa linha de pensamento vem ganhando cada vez mais espaço no meio acadêmico. De acordo com Thaler e Mullainathan (2000), a Economia Comportamental estuda como a combinação de conceitos econômicos, sociológicos e psicológicos pode explicar o que acontece na vida econômica real, em que os agentes econômicos apresentam limitações ao exercício da plena racionalidade. A teoria tradicional preconiza um mundo composto por agentes representativos com capacidade de operar de acordo com uma racionalidade ilimitada que lhes permite tomar decisões segundo a teoria de utilidade esperada e formar expectativas não-viesadas sobre eventos futuros. Assim, os aspectos psicológicos são ignorados dentro do arcabouço neoclássico.

O pressuposto de racionalidade ilimitada é um dos fundamentos da hipótese de mercados eficientes, segundo a qual os preços nos mercados financeiros incorporam todas as informações disponíveis, e estes preços são a melhor estimativa do valor fundamental dos ativos que estão sendo negociados. Herbert Simon, ao propor a incorporação de limites à racionalidade para tornar os modelos de tomada de decisão mais próximos à realidade, foi um dos primeiros economistas a atacar pressuposto de racionalidade ilimitada. Os estudos empíricos e experimentais têm mostrado que existem inúmeras situações em que os agentes não se comportam segundo a racionalidade prevista pela teoria neoclássica.

\footnotetext{
${ }^{20}$ Vencedor do prêmio Nobel de Economia em 1973, citado em Tvede (2000), ao comentar a aplicação de métodos matemáticos e estatísticos ao estudo da economia (característica dos modelos de expectativas racionais e de mercados eficientes).
} 
Por esta razão, os economistas comportamentais substituem o principal pressuposto da teoria neoclássica - o da teoria de expectativas racionais (racionalidade ilimitada) - pelo princípio da racionalidade limitada. Diversos autores têm argumentado que tais limitações, intrínsecas à natureza humana, devem ser incorporadas à análise econômica como extensão natural dos modelos atuais, uma vez que a evidência sugere tanto que os agentes são capazes de cometer certa variedade de erros sistemáticos como também que tais desvios causam importantes implicações econômicas. Teorias sobre o comportamento humano importadas da Psicologia e da Sociologia têm ajudado a dar maior sustentação teórica aos estudos empíricos sobre a dinâmica dos mercados financeiros, em que são recorrentes os movimentos de euforia e pânico que podem produzir sérias conseqüências econômicas, como demonstram as recorrentes crises financeiras desde o século XVII descritas anteriormente.

O conjunto de conhecimentos importados de outras áreas que constituem a Behavioral Economics mostram ainda que, para se analisar real people e não homo economicus, é preciso ir além da percepção de que existem limites à racionalidade (Jolls et al, 1998). Outros limites afetam os pressupostos de maximização de utilidade, preferências estáveis, expectativas racionais e ótimo processamento de informações, como os descritos pelo modelo de comportamento humano de Gary Becker. Tais limites podem ser descritos como a) bloqueadores da força de vontade (bounded willpower), que captura o fato de que muitas vezes as pessoas tomam decisões que não estão de acordo com seus interesses de longo prazo; e b) os limitadores do comportamento auto-interessado (bounded self-interest), uma vez que em determinados momentos as pessoas podem agir de maneira justa (se assim perceberem que os outros também estão sendo) e em outros de maneira oportunista (quando percebem que os outros podem estar agindo assim).

De acordo com Thaler e Mullainathan (2000), nos Estados Unidos, em 1993, 74\% das residências haviam doado recursos para instituições de caridade, com média dos valores situada em $2,1 \%$ da renda total do domicílio entrevistado. Os mesmos autores verificaram que $48 \%$ da população fizeram algum tipo de trabalho voluntário, com média de 4 horas semanais entre esse grupo. O comportamento altruísta pode até ser considerado racional, mas resultados similares são encontrados em experimentos econômicos em que as pessoas demonstram comportamentos conflitantes com a chamada racionalidade. As pessoas freqüentemente cooperam em jogos como Dilema dos Prisioneiros (o que não deveria ocorrer devido ao alto potencial de perda para um dos participantes se o outro agir de maneira oportunista) e rejeitam ofertas ruins em jogos como ultimate game, no qual um indivíduo faz uma oferta de parte do dinheiro que possui e, se a outra pessoa não aceitar, ninguém ganha nada. Em tese, a outra pessoa deveria aceitar qualquer oferta, mas geralmente as pessoas rejeitam as ofertas que não consideram "justas".

Essas características da natureza humana que afetam também o homo economicus podem ser divididas em dois grandes grupos: limites ao aprendizado e vieses do processo de tomada de decisão. Essa distinção é importante porque a seção 3 analisa as potenciais implicações sob a regulação dos mercados financeiros. Como vai ser notado mais adiante, essas implicações se referem mais aos chamados limites ao aprendizado, uma vez que os vieses do processo cognitivo fazem parte da natureza humana e são mais difíceis de alterar que as limitações ao aprendizado. Apresentam-se a seguir os principais conceitos desses grupos das Finanças Comportamentais, assim como as relações que estes têm com as evidências que têm comprovado que a hipótese de mercados eficientes nem sempre está presente nos mercados financeiros. 


\subsection{2) Fundamentos do comportamento não racional: Psicologia e Economia} nature".

"The economist may attempt to ignore psychology, but it is sheer impossibility for him to ignore human

John Maurice Clark ${ }^{21}$

De acordo com Tvede (2000), uma das primeiras tentativas de aplicar Psicologia à Economia foi provavelmente a do psicólogo francês Gabriel Tarde, que usou o conceito ao final do século XIX e acabou por publicar o livro Psychologie Economique, em 1902. Outro autor que usa conceitos de Psicologia para explicar fenômenos econômicos é Gustave Le Bon, autor de The Crowd, publicado em 1897. Mais tarde, a Escola Econômica Austríaca utiliza alguns conceitos psicológicos por meio de Hayek e Von Mises. Finalmente, George Katona (1975) publica livro nos Estados Unidos sobre Psicologia e Economia que ganha grande credibilidade em virtude dos exemplos reais em que o autor demonstra as bases de suas teorias.

Que os agentes econômicos sejam limitados em sua capacidade cognitiva parece ser um consenso mesmo entre os economistas defensores da teoria neoclássica, que dá enorme peso ao pressuposto de racionalidade ilimitada à conduta das pessoas. Entretanto, propõem tais teóricos que, apesar de existir racionalidade limitada, estas restrições não seriam importantes para o estudo econômico em geral, uma vez que são desvios irrelevantes do ponto de vista agregado, que em grande parte das vezes é explicado por modelos que têm sua origem em pressupostos de racionalidade ilimitada. O principal objetivo dos autores que atuam no campo da economia e das finanças comportamentais é mostrar que existem limites à racionalidade que ocorrem com freqüência significativa para provocar resultados econômicos relevantes. Visam, ademais, a incorporar tais limitações ao estudo da teoria econômica a fim de promover maior entendimento dos fenômenos econômicos no campo teórico.

Em resumo, pretendem basicamente responder à questão: existe uma ilusão teórica (os pressupostos neoclássicos produzem resultados muito diferentes da realidade) ou existe uma ilusão provocada pela anomalia verificada (existem desvios, mas eles são irrelevantes)? Conlisk (1996) descreve uma série de experimentos com indivíduos, realizados por especialistas em Economia Experimental, a fim de mostrar como eles reagem de fato a situações em que devem tomar uma decisão. Freqüentemente as pessoas tomaram, nos experimentos, decisões diferentes daquelas que pressupõem os modelos teóricos de tomada de decisão. Nessas situações, os agentes se mostraram incapazes de operar de acordo com o axioma da transitividade (se A é preferido a $\mathrm{B}$ e $\mathrm{B}$ preferido a $\mathrm{C}$, então $\mathrm{A}$ é preferido a $\mathrm{C}$ ), de entender perfeitamente conceitos básicos de Estatística, como a Lei dos Grandes Números, ignoraram informações relevantes, superestimaram informações irrelevantes e mostraram confiança exagerada nas suas previsões sobre eventos incertos, entre outros resultados que estão em oposição aos pressupostos de racionalidade ilimitada.

\footnotetext{
${ }^{21}$ Autor que publicou Economics and Modern Psychology (1918), citado em Tvede (2000).
} 


\subsubsection{1) Vieses no processo cognitivo (de tomada de decisões)}

A palavra "cognitivo" tem sua origem na palavra grega gnosco, que significa "conhecer" e do termo latino cogito, que significa "eu penso". De acordo com Tvede (2000), a Psicologia Cognitiva se refere a todos os processos pelos quais os impulsos sensoriais são transformados, reduzidos, elaborados, armazenados, recuperados e usados. Várias explicações têm sido propostas para explicar o chamado viés do processo cognitivo. Dentre os trabalhos feitos por psicólogos, destaca-se o de Kahneman e Tversky (1979), que propõe uma nova teoria de utilidade esperada para tomada decisão sob condições de risco. Esse trabalho, segundo Shiller (1999), teve provavelmente mais impacto do que qualquer outra teoria comportamental sobre o estudo econômico. De acordo com esses dois autores, a teoria de utilidade esperada hoje dominante não é boa para descrever as situações reais em que os agentes se deparam com condições de incerteza, uma vez que não incorpora elementos próprios da natureza humana, como os descritos a seguir:

Efeito certeza: pessoas tendem a dar maior peso às possibilidades que têm alta probabilidade de acontecer.

O exemplo 1 a seguir descreve a aparição do efeito certeza. $A=(x, p)$, em que x é o valor associado à probabilidade $\mathrm{p}$.

Situação 1: $\quad A=(4000,0.80)$ ou $B=(3000,1.0)$, pessoas escolhem $B(80 \%$ contra $20 \%)$.

Situação 2: $\quad \mathrm{A}=(4000,0.20)$ ou $\mathrm{B}=(3000,0.25)$, pessoas escolhem $\mathrm{A}(65 \%$ contra $35 \%)$.

Na situação 1, os agentes não são tomadores de risco, pois escolhem B mesmo tendo essa opção menor valor esperado que A (3000 x 3200). Isso não caracteriza um comportamento irracional, mas apenas avesso ao risco. Entretanto, na situação 2, os mesmos agentes, se não são tomadores de risco, deveriam novamente escolher B pois essa opção têm maior probabilidade que A. Mas isso não acontece. Este comportamento dos agentes viola o axioma da substituição da teoria de utilidade esperada. Esse axioma afirma que, se B é preferido a $A$, então qualquer combinação de $(\mathrm{A}, \mathrm{p})$ deve ser preferida a $(\mathrm{B}, \mathrm{p})$. Como a probabilidade de B na segunda situação continua sendo maior do que a de A, os agentes "deveriam" escolher B.

Efeito reflexão: quando expostos a situações que envolvem possibilidades de perda, os agentes demonstram estruturas de preferências conflitantes com aquelas pressupostas pela teoria de utilidade esperada. Os agentes tendem a ser avessos ao risco quando estão diante de duas possibilidades de ganho com a mesma utilidade esperada e tendem a ser tomadores de risco quando as mesmas possibilidades se apresentam em termos de perdas potenciais. (exemplo 2):

Utilizando a mesma situação 1 do exemplo anterior, pode-se descrever o efeito reflexão

Situação 1: $\quad \mathrm{A}=(+4000,0.80)$ ou $\mathrm{B}=(+3000,1.0)$, pessoas escolhem $\mathrm{B}(80 \%$ contra $20 \%)$.

Situação 2: $\quad \mathrm{A}=(-4000,0.80)$ ou $\mathrm{B}=(-3000,1.0)$, pessoas escolhem $\mathrm{A}(92 \%$ contra $8 \%)$.

Na primeira situação, os agentes são avessos ao risco, o que novamente não caracteriza por si só um comportamento não-racional. Contudo, quando o mesmo problema é apresentado em termos de perdas potenciais, os mesmos agentes passam a ser amantes do risco e escolhem a opção com maior perda esperada (mas com mínima chance de sair do jogo sem perda certa). 
Efeito isolamento: para simplificar o processo de tomada de decisão (de escolha), as pessoas geralmente desconsideram boa parte das características de cada uma das opções e centralizam sua análise sobre os componentes que distinguem as opções de escolha. Quando existe a separação entre os componentes comuns e distintos entre as escolhas possíveis, pode-se criar uma situação de preferências inconsistentes. Considerando a mesma situação 1 dos problemas anteriores, coloca-se um problema (exemplo 3) de duas etapas, como a seguir:

Há probabilidade de $75 \%$ de encerrar o jogo sem ganhar nada e de $25 \%$ de ir para a segunda etapa, em que há duas escolhas:

Situação após etapa 1: $\mathrm{A}=(4000,0.80)$ ou $\mathrm{B}=(3000,1.0)$.

Deve-se notar que neste jogo, em termos de resultados finais, tem-se a seguinte situação, considerando a junção das duas etapas em termos de probabilidades: Junção das duas etapas $\mathrm{A}=(4000,0.20)$ ou $\mathrm{B}=(3000,0.25)$, situação que se revela a mesma que a número 1 do exemplo do efeito certeza. Entretanto, ao contrário daquela situação, nesta os agentes escolheram a opção B (78\% x 22\%). O que se pode dizer é que as pessoas ignoraram a primeira parte do jogo, o que as levou a preferências inconsistentes com relação ao exemplo 1.

Dois temas importantes que provocam limites ao pleno exercício da racionalidade são, como expostos no trabalho de Shefrin (2000) sobre finanças comportamentais, chamados de heuristic-driven bias e frame dependence. Tais conceitos têm como base vários dos conceitos lançados por Kahneman e Tversky (1979).

\subsubsection{1) Regras de bolso viesadas (heuristic driven bias):}

Uma vez que a capacidade de processamento de informações por seres humanos é limitada, há necessidade de criar atalhos para o processo de tomada de decisões, os quais formulam soluções com custos relativamente baratos. De acordo com Simon (1976), decisões ótimas são custosas demais, o que torna natural a busca por soluções satisfatórias. $\mathrm{O}$ autor faz a distinção entre o que ele chama de "racionalidade substantiva" e a "racionalidade de procedimento" (substantive and procedural rationality). Por um lado, o comportamento é substantivamente racional quando é apropriado para se conseguir determinado objetivo com limites dados por condições e restrições. Assim, o comportamento racional depende tão somente dos objetivos. De acordo com a teoria tradicional, os agentes têm objetivos particulares (maximização de utilidade/lucros) e são substantivamente racionais. Estabelecidos estes pressupostos, os resultados econômicos podem ser obtidos com ferramentas matemáticas.

Por outro lado, o estudo da racionalidade de procedimento capta as dificuldades que podem se apresentar ao agente no processo de tomada de decisão. Embora exista um ótimo (racionalidade substantiva) para determinado problema e embora essas soluções possam ser encontradas por uma enumeração finita de possibilidades, muitas vezes encontrar o ótimo se torna impossível para problemas de qualquer complexidade. Para Simon, portanto, a teoria da racionalidade não é a teoria das melhores soluções (substantive rationality), mas sim a teoria dos procedimentos de eficiência computacional que levem a boas soluções (procedural rationality). Um dos resultados mais importantes retirados dos experimentos é que os erros cometidos pelos indivíduos acontecem de maneira freqüente e sistemática. De acordo com os autores que mostraram a ocorrência deste fenômeno, ele ocorre porque freqüentemente os agentes baseiam suas análises em regras de bolso (heuristics) para processar os dados. Este processo nada mais é do que a simplificação necessária para chegar a decisões satisfatórias. Shefrin (2000) ilustra o conceito com o exemplo seguinte: Qual a causa mais freqüente de morte nos Estados Unidos: homicídio ou derrame cerebral? Quando chamadas para responder a essa pergunta, as pessoas tendem a indicar o evento que está mais presente em sua mente. 
As pessoas têm tendência a prestar mais atenção a pequenas amostras em detrimento das grandes, principalmente quando se tratam de eventos recentes ou dramáticos (Camerer, 1998). Se a pessoa relembra ter presenciado mais episódios de homicídio do que mortes por derrame, então ela tenderá a responder homicídio. A situação descrita anteriormente leva a outro conceito, o da regra de bolso disponível (availability heuristic). Assim, as pessoas, além de utilizar regras de bolso para tomar decisões, recorrem geralmente àquelas que estão mais disponíveis do que outras, o que por si só já provoca um certo viés em um processo de escolha. Assim, chega-se também ao conceito de saliência, pelo qual os agentes utilizam informações mais fáceis de lembrar (Kahneman e Tversky, 1973).

Tanto o efeito "certeza" como o efeito "isolamento" parecem estar diretamente relacionados a este conceito da utilização de regras de bolso. Uma vez que as pessoas tendem a dar maior importância a eventos com probabilidades maiores independentemente de terem retornos esperados menores e considerando-se que elas procuram analisar apenas parte de determinado problema, parece razoável dizer que a utilização de regras de bolso para a análise do processo de tomada de decisão inclui tanto o efeito "certeza" como o efeito "isolamento". Além disso, as regras de bolso envolvem certo viés ${ }^{22}$, o que torna a escolha das regras voltada para alguma direção e promove a possibilidade de erros sistemáticos, uma vez que tais regras de bolso que direcionam a tomada de decisões dos agentes pode ser imperfeita. Por exemplo, se os agentes utilizam a mídia como fonte de informações importante para saber as causas de morte mais comuns e a maioria das reportagens são motivadas por homicídios, elas tenderão a achar que os homicídios são a maior causa de morte em vez dos derrames cerebrais.

Para se ter uma idéia do tamanho do erro, a cada morte por homicídio (resposta da maioria das pessoas) nos Estados Unidos, existem onze mortes por derrame cerebral (Slovic et al, 1979). Conlisk (1996) cita trabalhos de psicólogos que vêem as regras de bolso como uma das causas do viés em sistemas de tomada de decisão, assim como também consideram a utilização dessas regras de bolso como um problema de difícil solução. De acordo com os estudos, as regras de bolso, para um indivíduo com limitações em sua capacidade de exercer plenamente a racionalidade, são uma solução ótima, já que existe um alto custo ${ }^{23}$ para a inserção de raciocínios mais complexos no processo de tomada de decisão. Estudos realizados por psicólogos mostram que o viés permanece mesmo em situações em que aos indivíduos são oferecidos fortes incentivos, grande conhecimento a respeito da situação apresentada, melhores oportunidades de aprendizado, entre outras condições que deveriam atenuar a ocorrência de erros sistemáticos na tomada de decisões. Como mostra o trabalho de Slovic, Fischoff e Lichtenstein (1979), os resultados são atenuados pela incorporação dessas condições, porém tal diminuição da ocorrência de erros é limitada. O que a maioria dos estudos mostra é que a evidência do viés sugere que os indivíduos são capazes de cometer uma grande variedade de substanciais e sistemáticos erros relevantes para o estudo econômico do comportamento de tomada de decisão dos agentes.

As regras de bolso (heuristics), assim, são o meio pelo qual os agentes encontram soluções ótimas, levando em consideração os custos para tomar decisões plenamente racionais, uma vez que é da natureza humana a presença de limitações ao exercício da plena e ilimitada racionalidade. Como as regras são utilizadas com freqüência pelos agentes nos processos de tomada de decisão, em grande parte das vezes se baseiam em pressupostos incorretos e geralmente indicam soluções que seguem caminhos comuns, tornam-se regras de bolso viesadas. Assim, tais regras de bolso podem e muitas vezes levam os agentes a cometer erros sistemáticos.

\footnotetext{
${ }^{22}$ Certas regras de bolso são lembradas mais freqüentemente que outras (availability heuristic).

${ }^{23}$ Conlisk (1996) apresenta este conceito como custo de deliberação (deliberation cost).
} 
Como resume Shefrin (2000), o conceito de regras de bolso viesadas (heuristic-driven bias) traz consigo o pressuposto de que os agentes:

1. desenvolvem princípios gerais, regras de bolso (heuristics) para solucionar problemas;

2. crêem em regras de bolso para processar as informações levando em consideração os custos de operar com complexas soluções (deliberation cost); e

3. utilizam muitas vezes regras de bolso que contêm imperfeições.

O conceito de regras de bolso viesadas tem amplo efeito no estudo das finanças comportamentais. Um dos principais exemplos são as reações exageradas (overreaction) dos analistas e investidores com relação ao desempenho de ações que apresentam tendência de alta em detrimento daquelas que têm baixo desempenho recente.

\subsubsection{2) Frame Dependence / Aversão à perda}

De acordo com Shefrin (2000), a decisão dos agentes depende da maneira como um problema é apresentado a eles. Para a teoria tradicional ${ }^{24}$, os agentes não encontram problemas deste tipo, uma vez que a maneira como eles se apresentam é transparente, ou seja, é irrelevante levantar tal tipo de discussão porque os agentes formam suas preferências sobre um problema independentemente da maneira de como ele é apresentado. Entretanto, os estudos de Tversky and Kahneman (1981) e Thaler (1985 e 1987) sobre a dependência de como o problema é apresentado mostraram que as pessoas não têm habilidade para analisar os dados de um problema de maneira desvinculada à disposição do mesmo problema. Além disso, nossa memória seletiva também depende de como os dados são apresentados.

Um dos conceitos mais importantes que se originam desse chamado frame dependence é a contabilidade mental (mental accounting), que se refere à tendência humana de guardar determinados eventos em compartimentos mentais, geralmente baseando-se em atributos superficiais e absolutamente irrelevantes. Ademais, os mesmos trabalhos mostram que as pessoas vêem o mesmo problema em partes separadas e acabam avaliando as opções de resolução sem considerar o problema como um todo. Um exemplo disso é ilustrado em Thaler (1985): quando perdem algo (como um bilhete de teatro), as pessoas tendem a ser menos dispostas a adquirir o mesmo bem do que quando perdem o dinheiro que seria usado para comprar o mesmo bem. Ao perder o bem, o dinheiro já havia sido "alocado". O mesmo não acontece quando o dinheiro é perdido. As evidências têm mostrado que os agentes geralmente encontram dificuldades em manter o axioma da transitividade em todas suas escolhas. Um dos exemplos desse tipo de comportamento problemático é o descrito pelo efeito "reflexão", mostrado por Kahneman e Tversky (1979), que demonstra que as pessoas têm preferências distintas quando o mesmo problema se apresenta em forma de perda ou de ganho, como no exemplo a seguir, aqui descrito de maneira mais detalhada do que anteriormente:

Situação A: o agente deve escolher entre um ganho certo de $\$ 3000$ e $80 \%$ de chance de ganhar $\$ 4000$.

Situação B: o agente deve escolher ente uma perda certa de $\$ 3000$ e $80 \%$ de chance de perder $\$ 4000$.

\footnotetext{
${ }^{24}$ Os pressupostos neoclássicos de frame independence são encontrados em vários manuais de microeconomia, dentre eles Mas-Colell, Winston e Green (1995). Apesar disso, esses autores destacam os trabalhos de Kahneman e Tversky (1979).
} 


\begin{tabular}{|c|c|c|c|}
\hline \multicolumn{4}{|c|}{ Situação A (Ganho potencial) } \\
\hline Evento & Probabilidade & Valor esperado & Escolha \\
\hline Ganhar US\$ 3000 & $100 \%$ & US\$ 3000 & $\mathbf{8 5 \%}$ \\
\hline Ganhar US\$ 4000 & $80 \%$ & US\$ 3200 & $15 \%$ \\
\hline \multicolumn{4}{|c|}{ Situação B (Perda potencial) } \\
\hline Evento & Probabilidade & Valor esperado & Escolha \\
\hline Perder US\$ 3000 & $100 \%$ & (US\$ 3000) & $8 \%$ \\
\hline Perder US\$ 4000 & $80 \%$ & (US\$ 3200) & $\mathbf{9 2 \%}$ \\
\hline
\end{tabular}

Apesar de o problema apresentar payoffs idênticos para o agente, o fato de serem apresentados em formas de ganho e de perda provocam decisões diferentes para a grande maioria dos agentes. Na situação A, 85\% dos agentes escolheram a opção sem risco (ganhar $\$ 3000$ com certeza). Na situação B, $92 \%$ dos agentes escolheram a opção com risco (perder $\$ 4000$ com $80 \%$ de chance). Deve-se notar que, na situação A, o valor esperado da opção escolhida pela maioria dos agentes era menor do que a opção alternativa. Do mesmo modo, na situação B, o payoff da escolha preferida pelos agentes representa uma perda esperada maior do que a perda certa de \$3000. De acordo com Rabin (1998), em diversos contextos de tomada de decisão as pessoas são muito mais avessas à perdas do que são atraídas pelas mesmas quantias em ganhos.

O conceito de frame dependence mostra que diferenças na maneira de como um dado problema é apresentado pode produzir escolhas conflitantes. Essa relação explica por que as pessoas tendem a odiar perdas, sentindo-as por volta de 2,5 vezes mais do que ganhos na mesma proporção (Kahneman e Tversky, 1979). Isso significa que uma perda de 20 unidades monetárias provoca, na maioria das pessoas, uma desutilidade (insatisfação) maior, em termos absolutos, do que a utilidade (satisfação) de um ganho de 49 unidades monetárias (50 unidades de ganho seriam equivalentes a 20 de perda). Desse modo, pode-se dizer que as pessoas tendem a ser avessas ao risco quando expostas a problemas com resultados possíveis positivos e ao mesmo tempo tomadoras de risco em situações em que os resultados esperados são negativos.

Os autores utilizam a contabilidade mental, auto controle, arrependimento da decisão e aversão à perda para explicar tal comportamento. Por exemplo, investidores acreditam que limitar seu dispêndio aos dividendos é a estratégia ótima enquanto a venda das ações (que retornaria um ganho maior em virtude do sistema tributário) para fazer frente às despesas não seria ótima. Kahneman e Tversky fizeram uma hipótese adicional: existe um lado da mente que olha para o planejamento no longo prazo em detrimento do curto prazo, enquanto outra parte deseja gratificações de curto prazo. Esses dois lados estão em conflito constantemente. O exemplo que citam é o caso em que uma pessoa tem que escolher de onde irá tirar 600 dólares para comprar uma TV: se dos dividendos ou da venda de ações. Logo após a compra do aparelho, as ações sobem por algum motivo. Qual das decisões teria causado o maior arrependimento? Em tese, o agente deveria ser indiferente, pois poderia ter usado os dividendos para comprar mais ações. Mas não: é uma decisão custosa demais ficar de fora da alta (com menos ações). 


\subsubsection{2) Limites ao aprendizado:}

Como já descrito anteriormente, seria possível que tais erros no processo de tomada de decisão fossem eliminados se os agentes pudessem aprender com os erros e, assim, não torná-los parte de todas as tomadas de decisão em condições de risco. Entretanto, estudos de psicólogos e economistas mostram que existe também uma série de limitadores desse processo de aprendizado. Um deles é o chamado excessivo otimismo/confiança que as pessoas têm ao fazer julgamentos sobre eventos e sobre si mesmas. De acordo com a teoria de expectativas racionais, os agentes ao fazer previsões sobre eventos futuros utilizam e conhecem regras básicas da chamada Lei de Probabilidades, como a Lei dos Grandes Números e a formação de expectativas com base em probabilidades históricas.

Nos itens anteriores, utilizaram-se esses desvios de racionalidade com relação à teoria de utilidade esperada para mostrar como são criados os vieses no processo de tomada de decisão. Tenta-se, a partir de agora, mostrar como tais comportamentos impedem o processo de aprendizado por parte dos agentes econômicos. Os axiomas dos quais a teoria de utilidade esperada derivou são baseados em uma idéia de comportamento estritamente racional dos agentes (Savage, 1954). Entretanto, indivíduos violam sistematicamente as regras de Bayes e outras regras da teoria de probabilidades. Pessoas tendem a acreditar na "lei dos pequenos números" (dão peso exagerado a informações extraídas de pequena base de dados) ao mesmo tempo em que desconsideram dados históricos. A falta de compreensão sobre aleatoriedade também provoca a chamada "falácia do apostador" (gambler's fallacy), crença de que uma ocorrência recente de determinado resultado numa amostra de dados independentes provoca o aumento das probabilidades de resultados diferentes nas próximas ocorrências (se deu vermelho três vezes seguidas, então a probabilidade de dar preto aumenta; se a Bolsa sobre três dias consecutivos, então a probabilidade de haver "realização de lucros" - queda - aumenta). Clotfelter e Cook (1993) mostram que pessoas não apostam em números de loteria sorteados recentemente.

Pensamos que estamos acima da média em várias coisas, como honestidade e inteligência, que somos mais capazes como motoristas (cerca de $80 \%$ acha que está acima da média) e que também somos mais amigáveis que a maioria da população. Esses excessivos otimismo e confiança estão ligados também a processos cognitivos, mas principalmente às chamadas atitudes de defesa do ego (necessidade forte que temos de manter a harmonia entre nossas crenças e atitudes). A idéia de que os agentes econômicos são confiantes em excesso é muito antiga, como já mostrava Adam Smith: "The overweening conceit which the greater part of men have of their abilities is an ancient evil remarked by the philosophers and moralists of all ages." 25

Em mercados financeiros, isso provavelmente ajuda a explicar o excessivo volume negociado com ações, títulos e derivativos (Shiller, 1999), como já mostrado anteriormente. Outros dados também demonstram isso, como o fato de a taxa de turnover na Bolsa de Nova York oscilar ao sabor do otimismo ou pessimismo do mercado. Enquanto nas décadas de 50, 60 e 70 ficou em torno de $20 \%$, alcançou valores muito maiores em períodos de euforia (otimismo exagerado): $67 \%$ em 1930, 73\% em 1987. De acordo com a teoria econômica tradicional, se os agentes são racionais deveriam operar apenas quando houvesse a chegada de novas informações (nonspeculation theorem) ou quando houvesse demanda por ativos de maior liquidez em virtude de necessidades de diversificação (Geanakoplos, 1992).

\footnotetext{
${ }^{25}$ Adam Smith em Wealth of Nations, citado em Rubinstein (2000).
} 
Creditamos falhas geralmente a erros de outras pessoas, a má sorte ou a outros fatores não-controláveis, ao mesmo tempo em que os sucessos são devidos à nossa habilidade individual. $\mathrm{Na}$ grande maioria das vezes os indivíduos avaliam seu conhecimento de maneira muito otimista, pois acreditam que têm habilidades superiores à média da população. Por exemplo, previsões de probabilidades de eventos são, geralmente, exageradas (altas demais para eventos que acreditam que irão ocorrer e baixas demais para aqueles em que não acreditam), e os intervalos de confiança previstos pelos agentes são, em boa parte das vezes, muito pequenos, mesmo quando se pede que as pessoas façam estimativas com $99 \%$ de confiança. Tversky e Kahneman (1974) ligam o exagero à chamada heuristic representativeness, tendência que as pessoas têm a tentar categorizar eventos randômicos como padronizados ou mesmo a exagerar as probabilidades de eventos dramáticos ou raros desconsiderando as evidências de dados de médio e longo prazos. Analistas do mercado financeiro, assim como especialistas em outras áreas, exacerbam a tendência de excessiva confiança em suas habilidades de prever o movimento dos preços dos ativos negociados nesses mercados. Além disso, essas pessoas tendem a interpretar evidências de maneira contraditória a fim de torná-las coerentes com suas crenças preliminares. O fenômeno da reação exagerada (over/underreation) pode ser explicado pela teoria descrita, uma vez que essa reação está relacionada ao fato de que investidores tendem a superestimar as probabilidades de eventos recentes. Além disso, indivíduos tendem a exibir excessiva confiança e avaliam seu conhecimento e habilidades como superiores à média da população.

Quando chegam notícias, investidores revisam suas expectativas não de acordo com métodos objetivos bayesianos, mas exagerando o peso das informações mais recentes e dando menos importância ao passado e às informações de mais longo prazo a respeito do ativo que estão operando. Isso produz o que se chama de distribuição de impressões e não cálculos objetivos baseados na distribuição de probabilidades histórica. Essa tendência a buscar evidências (ou criá-las) que confirmem as avaliações preliminares (confirmatory bias) leva investidores a não admitir estratégias de investimento fracassadas e a não vender ativos em que estejam sofrendo prejuízo, fato que causa a persistência de precificação incorreta com relação aos fundamentos econômicos (Shefrin e Statman, 1985). Esse conceito está ligado ao que os psicólogos chamam de ancoramento (anchoring): pessoas, quando fazem projeções, são extremamente influenciadas por suas prévias crenças e opiniões. Além disso, usam evidências fracas para formar suas hipóteses iniciais e a estas ficam "ancoradas", com grande dificuldade de corrigi-las quando informações de melhor qualidade posteriormente contradigam as crenças iniciais (Rabin, 1998).

Em estudo conduzido por Tversky e Kahneman (1974), quando perguntadas sobre o número de países africanos que pertencem à ONU, as pessoas deram suas respostas ancoradas em valores que nada tinham a ver com a pergunta feita. Antes de darem suas respostas, os pesquisadores rodaram uma "roda da fortuna" com valores entre 0 e 100. Para um primeiro grupo, o valor da "roda" foi de 10 e do outro, 65. A mediana das respostas do número de países para os grupos acabou correlacionada com os irrelevantes valores da roda fortuna. $\mathrm{O}$ primeiro grupo respondeu 25 e o segundo, 45. Além disso, existe a chamada dissonância cognitiva, um conflito mental que ocorre quando as pessoas verificam que suas crenças e pressupostos se mostram errados e, por isso, agem de maneira a minimizar esse medo de se arrepender de terem feito escolhas erradas no passado (Shiller, 1999). ${ }^{26}$

\footnotetext{
${ }^{26}$ De acordo com Shiller, o primeiro autor a explorar esse tipo de comportamento foi Festinger (1957).
} 
Essa forma de anchoring não implica que as pessoas necessariamente interpretem de maneira errada a nova informação, mas que ignoram boa parte de seu conteúdo. Entretanto, trabalhos como o de Rabin e Schrag (1997) demonstram que as pessoas tendem a interpretar de maneira errada novas informações com objetivo de reforçar suas crenças iniciais. Esse tipo de viés foi encontrado em diversos estudos. De acordo com pesquisa de Shiller (1999), investidores que acreditavam que as ações do mercado acionário japonês estavam com relações preço/lucro baixas na década de 80 passaram a acreditar que aquelas se encontravam caras nos anos 90 (com relações preço/lucro altas). Enquanto em 80 os investidores eram "ancorados" pelos sucessivos retornos positivos das ações, o contrário aconteceu após o estouro da "bolha" japonesa em 1989. De lá para cá, o Nikkei (principal índice de ações japonês) baixou de 40 mil pontos para 9 mil. Segundo Shiller (2000a), em 1929 eram várias as pessoas de renome, como o ilustre professor Irving Fisher e o Presidente dos Estados Unidos (Hoover), que não queriam rever suas crenças iniciais quando o preço das ações começou a declinar. Ao contrário disso, declarações de analistas (como Robert Babson), que acreditavam que um crash estava por vir, eram ridicularizadas (Tvede, 2000).

Por outro lado, o cotidiano das finanças corporativas mostra a todo instante exemplos de atitudes que passam longe da racionalidade e têm ligação com comportamentos típicos de excessivo otimismo ou confiança, como os demonstrados anteriormente na seção de exemplos de "anomalias". Enquanto muitos argumentam que fusões e aquisições criam sinergias lucrativas, os beneficários dessa sinergia geralmente são os vendedores e não os compradores.

Um tipo particular de exagerada confiança que ocorre com certa freqüência é a tendência dos agentes a considerar irrelevantes acontecimentos passados (irrelevância da História) ao mesmo tempo em que dão exagerada importância para fatos atuais quando fazem avaliações sobre eventos futuros. É comum verificar que investidores não utilizam lições que possam ser extraídas de dados históricos de mais longo prazo para verificar correlações entre preços e tomam decisões verificando relações causais recentes (Shiller, 1999).

Outro fator que influencia a capacidade de aprendizado pelos agentes econômicos é a chamada ilusão (de conhecimento ou de controle). As pessoas têm tendência a acreditar que a acurácia de suas previsões será tanto maior quanto maior forem as informações a respeito do evento futuro. Entretanto, quantidade de informações não implica maior possibilidade de prever corretamente, pois não necessariamente as novas informações são melhores que as já existentes (Hirshelifer, 2001). A ilusão de controle se refere à crença de que temos alguma influência sobre eventos puramente incontroláveis. Apostadores tendem a oferecer mais dinheiro por bilhetes preenchidos por números de sua preferência do que por bilhetes que contêm números escolhidos ao acaso. Além disso, somos mais propensos a apostar "cara ou coroa" antes de a moeda ser lançada do que quando ela já foi jogada e seu resultado é desconhecido. ${ }^{27}$ Basicamente as pessoas, neste caso, acreditam que podem influenciar o resultado "enquanto a moeda está no ar".

O último dos fatores psicológicos que dificulta o aprendizado por parte dos agentes econômicos é um viés conhecido como hindsight bias: a tendência de se acreditar que é possível prever o resultado de eventos futuros com antecipação. Como diz o psicólogo Max Baerzman, especialista em teorias sobre negociações que utiliza conceitos de Economia Comportamental em suas análises, "todos nós temos uma incrível habilidade de prever o passado" (Bazerman e Neale, 1994). Na verdade, pode-se dizer que isso é o chamado determinismo histórico, tendência a acreditar que eventos históricos poderiam ser antecipados pelas pessoas que os vivenciaram ou que pelo menos as pessoas teriam boas chances de prever tais eventos.

\footnotetext{
${ }^{27}$ Outros exemplos disso são encontrados em Thaler (1992).
} 


\subsection{3) Limites à arbitragem}

O contra-argumento dado pelos defensores da teoria neoclássica é que tais desvios (anomalias) acontecem de maneira randômica ${ }^{28}$ e não provocam resultados, no agregado, que alterem aqueles previstos pelos modelos baseados em expectativas racionais. Ademais, os agentes passariam por um processo de aprendizagem (evolução) que os levaria a não cometer erros sistemáticos com o passar do tempo, porque tais erros seriam reduzidos rapidamente ao deixarem oportunidades de arbitragem para outros agentes, acelerando o processo de ajuste do mercado. Rubinstein (2000) e Fama (1998) contestam os resultados empíricos encontrados pelos autores das Finanças Comportamentais. De acordo com eles, a falta de generalidade é o principal problema dos estudos em behavioral finance. Assim, as chamadas anomalias em finanças nada mais seriam do que resultados aleatórios ou então ocorrem por problemas de especificação dos testes. A existência de anomalias não poderia ser persistente porque isso traria oportunidades de retorno, ajustado ao risco, anormais a investidores que percebessem tais distorções.

A Economia Comportamental considera, contudo, que:

1. Existem evidências que comprovam que os agentes podem cometer erros sistemáticos, ou seja, os erros de avaliação não se comportam de maneira aleatória .

2. Existem limites à arbitragem porque várias decisões (erradas) dos agentes não necessariamente criam oportunidades de arbitragem sem risco a outros agentes. ${ }^{29}$ Entre esses limites, podem-se mencionar os seguintes:

a. Em um ambiente com investidores irracionais, um investidor racional pode conseguir lucros apostando que o mercado continue a seguir a tendência "errada". Alguém que tivesse comprado tulipas ou ações da Nasdaq no início da euforia teria ganhado.

b. Arbitragem nos casos de desvios com relação aos fundamentos é uma atividade que envolve risco e às vezes altos custos de transação (como custos de corretagem e depósito de altas margens de garantia), razão pela qual a demanda por arbitragem é limitada.

c. Arbitradores geralmente administram recursos de terceiros e são avaliados periodicamente. Dessa forma, não podem insistir em operações em que os preços demoram a se ajustar. O caso do LTCM, citado anteriormente, é um bom exemplo disso.

3. Há várias situações em que os agentes têm pouca (ou quase nenhuma) oportunidade de aprendizado. $^{30}$

\footnotetext{
${ }^{28}$ De acordo com os trabalhos de um dos pais da Teoria de Mercados Eficientes, Eugene Fama, como Fama (1998), a teoria neoclássica não pressupõe que os agentes não cometam erros nem que esses erros não possam ser grandes. Entretanto, tais erros, por ocorrerem de maneira randômica (com média zero), não produzem desvios significativos.

${ }^{29}$ Para maiores detalhes sobre os limites à arbitragem, ver Shleifer (2001).

${ }^{30}$ Um exemplo é a situação em que o agente deve decidir como aplicar seu dinheiro ao longo da vida visando à aposentadoria. Nesse caso, os agentes simplesmente não têm oportunidade de aprendizagem.
} 
Apesar de os pressupostos neoclássicos serem irrealistas (racionalidade, força de vontade e auto-interesse ilimitados), a força teórica da Economia Comportamental também vem de suas previsões $^{31}$. Nesse contexto, a análise comportamental é coerente com o preceito proposto por Milton Friedman, segundo o qual: "economics should not be judged on whether the assumptions are realistic or valid, but rather on the quality of its predictions" ${ }^{32}$ (Cunningham, 1994). As previsões das análises da Economia e das Finanças Comportamentais são próximas do que acontece na realidade, por exemplo, dos mercados financeiros. Se os modelos neoclássicos de expectativas racionais tivessem grande poder explicativo, certamente a análise comportamental teria reduzida ou nenhuma audiência entre acadêmicos e profissionais do mercado financeiro. ${ }^{33}$

Em resumo, pode-se dizer que behavioral finance surge como uma subdisciplina de behavioral economics e concentra sua análise em dois pressupostos fundamentais: 1) a racionalidade limitada dos investidores, diferentemente da racionalidade ilimitada prevista pela HME, contribui de maneira significativa para a formação de preços porque 2) há limites à arbitragem, uma vez que investidores racionais não conseguem formular estratégias operacionais sem risco a fim de obter lucros com a ação dos chamados noise traders. O termo noise faz referência a investidores que tomam decisões não-racionais. O termo, talvez uma forma mais politicamente correta de se referir a investidores irracionais, foi usado primeiramente por Black (1986), mas a intuição do chamado limite à arbitragem já podia ser encontrada em Keynes (1936): "os mercados financeiros podem continuar irracionais por mais tempo do que você consegue se manter solvente".

Apesar do reconhecimento da existência de noise traders por autores como Friedman e Fama, sua importância para o comportamento dos preços nos mercados financeiros é quase sempre ignorada nos trabalhos em que se parte de premissas como a hipótese de expectativas racionais. $\mathrm{O}$ argumento para essa desconsideração é o fato de que arbitradores racionais operariam contra os noise traders, trazendo os preços para seu nível fundamental. Além disso, "speculators on ... average sell ... low ... and buy ... high", segundo Friedman (De Long et al, 1990).

Entretanto, como mostram as pesquisas de finanças comportamentais, existem limites à arbitragem, que são importantes para entender o funcionamento do mercado financeiro porque os arbitradores não são investidores totalmente amantes do risco ${ }^{34}$ e não podem garantir que eventuais distorções causadas pelos noise traders possam até mesmo aumentar com o passar do tempo. Em resumo, pode-se dizer que o fato de os preços estarem, pela ação dos noise traders, afastados do valor fundamental não implica necessariamente que existam oportunidades de lucro

\footnotetext{
${ }^{31}$ Por exemplo, investidores têm tendência a demonstrar aversão à perda (loss aversion), o que é consistente com o fato de que ações que tiveram retorno negativo em período recente apresentam volumes de negócio inferiores às ações que tiveram retorno positivo em período recente, como mostram os trabalhos de Lakonishok and Smidt (1986) e Ferris et al (1988).

${ }^{32}$ Friedman (1953).

${ }^{33}$ Apesar de ainda ter penetração restrita na academia, principalmente no Brasil, várias empresas de gestão de recursos de terceiros vêm utilizando conceitos das Finanças Comportamentais para oferecer um estilo de administração de recursos em que se tenta tirar proveito do comportamento não plenamente racional dos investidores nos mercados financeiros. Entre essas empresas, destacam-se: Fuller and Thaler Asset Management fundada por um dos pioneiros em Finanças Comportamentais, Richard Thaler, e que administra mais de US\$1,5 bilhão; LSV Asset Management (empresa de outros três pesquisadores da área - Lakonishok, Shleifer e Vishny); Martingale Asset Management; e Pangora Asset Management (que administra mais de US\$ 14 bi). Dentre os bancos, um dos pioneiros a lançar fundos de investimento que usam um approach comportamental foi o ABN Amro Bank (http://www.abnamroam.com.sg/sitemap.htm).

${ }^{34}$ Como já dito anteriormente, vale notar que a grande maioria desses investidores são administradores de fundos de investimentos e, assim, fazem a gestão de recursos de terceiros. Como geralmente são avaliados por seu desempenho no curto prazo, não podem assumir o risco de fazer uma arbitragem que possa demorar muito a trazer lucros (Thaler \& Mullainathan, 2000).
} 
sem risco ${ }^{35}$ a arbitradores que percebem tal distorção, ou seja, como mostram Barberis e Thaler (2001):

$$
\text { prices are right } \Rightarrow \text { no free lunch } \quad \text { (Hipótese de mercados eficientes) }
$$

$\operatorname{mas} \ldots$

no free lunch $\neq$ prices are right (Limites à arbitragem/behavioral finance)

Por essas razões, behavioral finance substitui o pressuposto das expectativas racionais e dos mercados eficientes pelo princípio da racionalidade limitada. Para autores como Thaler \& Mullainathan (2000) e Shiller (1999), tais limitações são intrínsecas à natureza humana e devem ser incorporadas à análise econômica como extensão natural dos modelos atuais, uma vez que as evidências sugerem tanto que os agentes são capazes de cometer certa variedade de erros sistemáticos, como também que tais desvios têm relevantes implicações econômicas.

Como ressaltado por diversos pesquisadores de Finanças Comportamentais, o principal objetivo desta linha de investigação não é rejeitar totalmente a abordagem neoclássica de finanças, mas mostrar como e por que os pressupostos e explicações tradicionais não são suficientes para a compreensão de muitos acontecimentos dos mercados financeiros principalmente das crises financeiras. Busca-se demonstrar que, por causa de pressupostos irrealistas como o da racionalidade ilimitada, a visão neoclássica só se aplica a circunstâncias particulares. O novo programa de pesquisa incorpora conceitos da Psicologia, da Sociologia e de outras ciências para aproximar a teoria econômica e a teoria das finanças à realidade dos mercados financeiros.

\section{2) Aversão à perda e outras anomalias no Brasil}

De acordo com a hipótese de mercados eficientes, as conseqüências de regras tributárias sobre os ganhos auferidos em transações com ações deveria produzir padrões previsíveis no volume de negociação das ações. Por outro lado, não deveria haver nenhuma relação entre preços passados e volume negociado no presente. Uma vez que ganhos ou perdas de capital são considerados para efeito tributários apenas quando realizados, investidores têm grande incentivo em realizar perdas, uma vez que a base de cálculo para ganhos de capital vai ser diminuída com a inclusão de perdas (Constantinides, 1983 e 1984).

Entretanto, diversos estudos mostram que existem outros motivos que levam investidores a tomar decisões de compra e venda de ações que não estão relacionados a questões tributárias ou a formação de expectativas com relação ao valor das empresas. Tais estudos mostram que existe uma assimetria de volume nos mercados de ações entre os períodos de tendência de alta nos preços e nos de baixa. O padrão de volume (medido em termos de turnover) encontrado após retornos positivos é maior que o encontrado após baixas sucessivas. Os estudos prévios sobre o tema ofereceram suporte à hipótese de que investidores se desfazem de ações vencedoras mais rapidamente do que vendem as ações em que estão sofrendo prejuízo. Investidores teriam comportamento parecido com o descrito pela prospect theory de Kahnemam e Tversky (em que a desutilidade de uma perda tem maior peso que a utilidade de um ganho de mesmo tamanho em termos de unidades monetárias) ou então teriam uma expectativa incorreta de certa reversão à média dos preços. Como já mostrado anteriormente, as pessoas têm tendência não plenamente racional a tomar riscos em situações de perda (para fugir de perdas certas) e serem conservadoras em situações de ganho (para ter ganho certo).

\footnotetext{
${ }^{35}$ No jargão econômico, isso quer dizer que não existiria uma situação de free lunch provocada pela ação de investidores não-racionais.
} 
Também entram aqui as chamadas atitudes de defesa do ego, ligadas ao conceitos de limitadores do aprendizado, como anchoring. Adaptamos nossas atitudes para que elas sejam coerentes com decisões tomadas no passado, mesmo que os fatos mostrem que estão erradas. Se determinado investidor compra ações e elas sobem rapidamente, tem grande tendência a vender e confirmar sua decisão passada correta auferindo o lucro. Se por outro lado os preços caem, tornam-se investidores de longo prazo e as mantêm em carteira. Vender ações que estão dando prejuízo é também uma prova de que se cometeu um erro, e as pessoas geralmente tentam fugir de ações que confirmem seus erros. Além disso, como já descrito anteriormente, sofremos da chamada dissonância cognitiva. Se os preços caem, não é a decisão de compra passada que está errada e sim "o mercado que está errado", dizem geralmente os investidores. Preços em alta também aumentam a chamada excessiva confiança. Com lucros, os investidores se sentem mais confiantes em realizar novas operações porque superestimam suas habilidades em prever os preços futuros das ações que negociam.

Alguns autores, como Lakonishok e Smidt (1986) e Harris et al (1988) tentam listar motivos que poderiam justificar esse fenômeno com base no comportamento racional de investidores. Eles podem vender winners mais rapidamente por motivos de diversificação (tais ações vencedoras passariam a ter participação desproporcional na carteira). Entretanto, por esse motivo, os investidores deveriam realocar comprando mais ações losers (pois estas teriam sua participação diminuída), mas isso não acontece. Outro motivo estaria relacionado à compra baseada em informações favoráveis. Com preços subindo, tais informações estariam sendo incorporadas, e os motivos para se mantê-las não mais existiriam, levando os investidores a vender winners. $\mathrm{O}$ mesmo não aconteceria com losers porque tais informações não estariam incorporadas "ainda". Essa hipótese pode até ser próxima da realidade, mas está longe de ser coerente com um comportamento racional. Sob o prisma de expectativas racionais, por que determinado investidor acharia que tem informações favoráveis que não são disponíveis a todos os outros agentes? Tal explicação está mais próxima de uma espécie de comportamento de excessiva confiança. Investidores podem achar que sabem analisar melhor as informações do que outros, assim como acham que são motoristas acima da média. Outro argumento se relaciona ao fato de que potencialmente os custos de transação podem ser maiores para losers do que para winners. Contudo, por que necessariamente o valor de winners é maior que o de losers? É perfeitamente possível que aconteça o contrário.

\section{1) Base de dados e metodologia para testar aversão à perda}

Neste item, procura-se testar empiricamente se os volumes anormais (aqui medidos em termos de números de negócios) são explicados pelo retorno passado de uma ação. A taxação sobre ganhos de capital cria incentivos para realizar vendas de ações previamente adquiridas ou deferir tal venda. Se um investidor tem ações em que está perdendo e em que está ganhando, deve ter propensão maior a realizar as perdas porque elas podem compensar os ganhos (diminui a base de cálculo do IR, que hoje é de $20 \%$ dos ganhos líquidos). Tais incentivos podem estar relacionados à taxação, como descrito anteriormente. Se o volume anormal de winners (ações que tiveram retorno passado positivo) for maior que o das losers, então os motivos relacionados à taxação não servem para explicar esse comportamento.

A metodologia usada é inspirada no artigo de Lakonishok e Smidt (1986), em que os autores utilizam dados de ações de duas Bolsas dos Estados Unidos (NYSE e ASE) com dados de volume (quantidade de ações e não em volume financeiro, para controlar pelo tamanho da empresa) mensal e preço entre os anos de 1968 e 1982. Calculou-se o turnover (número de ações 
negociadas pelo total emitido) médio do mercado e depois a diferença entre o turnover de cada uma dependendo do período que estava sendo analisado e o turnover médio.

Os dados foram analisados a partir da regressão a seguir:

Volume anormal $(\mathrm{AV})=\mathrm{a}+\mathrm{bDN}+\mathrm{e}$, em que DN é uma variável binária com valor $1 \mathrm{se}$ o retorno passado é positivo ou 0 se for o contrário. Os períodos para definição do retorno foram de 5, 11, 23 e 35 meses. Para todos os períodos de definição os turnovers eram maiores para winners do que para losers. Em tese existe um problema com a base de dados utilizada. Muitas vezes existem negócios que são transferências de grandes posições entre bancos/fundos (aqui no Brasil estes negócios são os chamados "diretos"). Isso geralmente distorce o volume (quantidade ou volume financeiro) em determinado mês. Para corrigir este problema, utiliza-se neste trabalho o número de negócios como variável a ser explicada.

Considerou-se uma tabela para classificar os volumes com relação à média em cada ano:

\section{Faixa de variação do número de negócios}

\section{Classificação adotada}

Mais que $50 \%$ menor do que a média do ano

Entre $50 \%$ e $10 \%$ menor do que a média do ano

Entre $10 \%$ menor e $10 \%$ maior do que a média do ano

Entre $10 \%$ e $50 \%$ maior que a média do ano

Mais que $50 \%$ maior que a média do ano

$-2$

$-1$

0

$+1$

$+2$

Alguns tipos de variável de escolha multinomial são inerentemente ordenados, de acordo com Greene (1997). Ratings de títulos de dívida (bonds) são expressos em categorias (AAA, $\mathrm{AAB}, \mathrm{ABB}$, por exemplo), dados de pesquisas de opinião, estado de ocupação (empregado, desempregado, empregado parcialmente) ou mesmo faixas de renda familiar. Para estes casos, os modelos logit e probit multinomiais não são eficientes porque não conseguem capturar as informações adicionais presentes na natureza ordinal da variável dependente.

Nem mesmo o método de mínimos quadrados ordinários seria apropriado porque a codificação da variável dependente nestes casos (geralmente $0,1,2,3$, e assim por diante) reflete somente um ranking: a diferença entre 1 e 2 não pode se considerada como equivalente à diferença entre 2 e 3, por exemplo (Kennedy, 1997). Nestes casos os modelos de escolha ordenada são utilizados. Eles são construídos, de acordo com Greene (1997), da mesma maneira que os modelos probit binomiais e da seguinte maneira:

$$
y^{*}=\beta^{\prime} x+\varepsilon
$$

Como sabido, $\mathrm{y}^{*}$ não é observável. O que se observa é que:

$$
\begin{aligned}
& \mathrm{y}=0 \text { se } y^{*} \leq 0, \\
& \mathrm{y}=1 \text { se } 0<\mathrm{y}^{*} \leq \mu 1, \\
& \mathrm{y}=2 \text { se } \mu 1<\mathrm{y}^{*} \leq \mu 2, \\
& \cdots \\
& =\mathrm{J} \text { se } \mu_{J-1} \leq y^{*}
\end{aligned}
$$


Assim, operamos os dados com modelo de escolha ordenada, considerando os períodos de 5, 8, 11 e 17 meses para definição dos períodos analisados. Consideram-se como retornos os preços médios dos meses analisados. Neste caso, a equação poderia ser descrita da seguinte maneira:

$y^{*}=\beta^{\prime} x+\varepsilon$, em que:

y* é o número de negócios do mês posterior ao período em que se analisou o retorno.

$\beta^{\prime}$ é o retorno médio entre os períodos de análise $(5,8,11$ e 17 meses)

A seguir os resultados encontrados para os coeficientes: se estes forem positivos, significa que retornos positivos implicam que a faixa do número de negócios será maior do que a média anual, ou seja, os preços passados (no caso positivo) implicam maior número de negócios para determinada ação. Por outro lado, retornos negativos implicam menor volume de negócios em período posterior. $\mathrm{O}$ que se encontra é que, na grande maioria dos casos, os volumes (medido em termos de número de negócios) são positivamente correlacionados aos preços passados de determinada ação.

\begin{tabular}{|c|c|c|c|c|c|c|c|c|}
\hline \multirow[t]{2}{*}{ Ação } & \multicolumn{2}{|c|}{5 meses } & \multicolumn{2}{|c|}{8 meses } & \multicolumn{2}{|c|}{11 meses } & \multicolumn{2}{|c|}{17 meses } \\
\hline & Coeficiente & Significância & Coeficiente & Significância & Coeficiente & Significância & Coeficiente & Significância \\
\hline Banco do Brasil & 0.024148 & 0.0000 & 0.041548 & 0.0511 & 0.052618 & 0.0031 & 0.065821 & 0.0225 \\
\hline Acesita & 0.012757 & 0.0001 & 0.045671 & 0.0311 & 0.001254 & 0.0011 & 0.045517 & 0.0333 \\
\hline $\begin{array}{r}\text { Cia Siderúrgica } \\
\text { Tubaraão }\end{array}$ & 0.004890 & 0.0629 & 0.002890 & 0.0129 & 0.005590 & 0.0129 & 0.001190 & 0.0629 \\
\hline Fosfértil & 0.015201 & 0.0000 & 0.005501 & 0.0022 & 0.00011 & 0.0010 & 0.068201 & 0.0545 \\
\hline Bradesco & 0.002673 & 0.0245 & 0.006603 & 0.0095 & 0.001144 & 0.0745 & 0.001173 & 0.0780 \\
\hline Petróleo Ipiranga & 0.017570 & 0.0175 & 0.000570 & 0.0875 & 0.05550 & 0.0675 & 0.042170 & 0.0555 \\
\hline Light & 0.120830 & 0.1208 & 0.090830 & 0.0963 & 0.095430 & 0.1028 & 0.01530 & 0.1108 \\
\hline Sabesp & 0.012122 & 0.0235 & 0.055122 & 0.0475 & 0.056822 & 0.0891 & 0.054522 & 0.0025 \\
\hline Eletrobrás & 0.051233 & 0.0000 & 0.04211 & 0.0012 & 0.000233 & 0.0001 & 0.011133 & 0.0005 \\
\hline Itaú & 0.033232 & 0.0654 & 0.003211 & 0.0874 & 0.011132 & 0.0450 & 0.07845 & 0.0123 \\
\hline Inepar & 0.002144 & 0.0249 & 0.001457 & 0.0124 & 0.00369 & 0.0178 & 0.00145 & 0.0149 \\
\hline
\end{tabular}

Obs: os valores em negrito e itálico são estatisticamente significantes a $10 \%$ de confiança, os em negrito a $5 \%$ de confiança e os demais não são significantes a $10 \%$ de confiança. 


\section{2) Outros estudos empiricos sobre Finanças Comportamentais no mercado financeiro brasileiro}

Apesar de ser muito incipiente a pesquisa sobre Finanças Comportamentais no Brasil, alguns estudos já realizados com dados do mercado financeiro local replicam testes empíricos feitos em outros países, principalmente nos Estados Unidos. Embora existam alguns trabalhos empíricos sobre anomalias, como os encontrados em Costa Jr et al (2001), poucos deles buscam fundamentos teóricos nas Finanças Comportamentais para explicar os resultados encontrados. A exceção é o trabalho de Costa Jr. (1993), que utiliza as mesmas explicações de De Bondt e Thaler (1985).

Em seu estudo, Costa Jr., trabalhando com dados do mercado brasileiro anteriores a 1993, encontra os mesmos resultados de De Bondt e Thaler. Existem reações exageradas (overreaction) dos analistas e investidores com relação ao desempenho de ações que apresentam tendência de alta em detrimento daquelas que tem baixo desempenho recente. Assim, comparando um portfolio de ações perdedoras contra um portfolio de ações vencedoras, verificase que o retorno da primeira carteira é superior ao da segunda. Recentemente, Dall'agnol (2002) atualizou o estudo com dados mais recentes e confirmou os resultados encontrados por Costa Jr. 


\section{3) Finanças comportamentais e governança para os investidores (investor governance)}

Esta seção se relaciona a uma tentativa de analisar em que medida essa nova abordagem à teoria de finanças pode trazer implicações no campo da política econômica com relação à regulação e à supervisão do mercado financeiro. Vale frisar o caráter especulativo e nãoconclusivo, mesmo do ponto de vista teórico, dessa pesquisa, uma vez que são escassas as análises mais sistemáticas nesta área. Apesar de as análises e conceitos descritos a partir de agora serem ainda pouco discutidas, parece ser muito importante incorporar os conceitos de Finanças Comportamentais à reflexão sobre a realidade brasileira para aprofundar a compreensão do funcionamento dos mercados financeiros, subsidiando assim o trabalho dos órgãos governamentais que os regulam (como Banco Central e Comissão de Valores Mobiliários).

\section{1) Economia do Direito (Law and Economics)}

Law and Economics (ou Economic Analysis of Law) é a análise do Direito com base nos pressupostos e metodologias econômicos, com o objetivo de: 1) usar a Economia para estudar os efeitos das normas legais e 2) determinar, com base em princípios econômicos, regras legais ótimas (ou mais eficientes) (Hovenkamp, 1995). Entretanto, várias definições diferem em certo aspecto da apresentada anteriormente, como a de Richard Posner ${ }^{36}$, que define a disciplina como a aplicação de metodologias da economia neoclássica ao estudo das normas legais (Cunningham, 2000). Apesar de sempre ter havido economistas preocupados com aspectos legais, é a partir da década de 60 que se disseminam os estudos na área da Economia do Direito. Os trabalhos de Ronald Coase - Nature of Firm (1937) e The Problem of Social Cost (1954) - disseminam a idéia de que as transações econômicas englobam não apenas objetos de direito, mas direitos de propriedade sobre determinado bem em todas suas dimensões (o próprio bem e seus resíduos todos os direitos intrínsecos ao bem, no caso de ações o direito ao voto, os dividendos, etc). $\mathrm{O}$ último deles tem grande influência no crescente interesse dos economistas pela análise do Direito $^{37}$.

Baseados na interpretação simplista do chamado Teorema de Coase, economistas da Universidade de Chicago passam a fazer seus estudos sobre o Direito alicerçados nos rigorosos pressupostos neoclássicos comportamentais de maximização de utilidade/lucros e racionalidade ilimitada e no positivismo metodológico. O chamado Teorema de Coase pode ser interpretado como favorável aos pressupostos neoclássicos uma vez que propõe que, em um mundo em que os custos de transação são nulos, haveria todos os argumentos favoráveis a deixar os mercados livres de regulação. Entretanto, o próprio Coase não concorda com a afirmação de que os custos de transação são iguais a zero. Mais do que isso: segundo ele, a grande maioria das leis relacionadas a aspectos econômicos são mecanismos que procuram lidar com os problemas advindos dos custos de transação.

\footnotetext{
${ }^{36}$ Juiz da Suprema Corte dos Estados Unidos e autor de várias obras sobre Economia do Direito.

${ }^{37}$ Alguns autores, como Stigler (1992), chegam a dividir a análise econômica do Direito entre os períodos BC e AC (before and after Coase). É importante notar que em 1958 é fundado o Journal of Law and Economics na Universidade de Chicago, ainda hoje o principal centro de estudos nesta área.
} 
Apesar disso, são poucos os autores que tratam a Economia do Direito sem considerar os pressupostos neoclássicos como base primordial. A análise econômica do Direito relacionada a corporações, por exemplo, considera que os preços das ações das companhias abertas negociadas publicamente são a melhor estimativa do valor da empresa. Essa forte ligação entre a Economia do Direito e a Economia Neoclássica levou à inevitável incorporação de outros pressupostos econômicos elaborados com os mesmos pressupostos, como a HME, que, em sua essência, pressupõe que investidores agem com racionalidade ilimitada ao operar nos mercados financeiros. Entre os pesquisadores da área da Economia do Direito a influência da HME é tão dominante $^{38}$ que vários deles chegam a afirmar que o contexto de mercados eficientes era o "único" em que se poderiam discutir mercados e sua regulação (Cunningham, 2002). Algumas leis são claramente baseadas nos pressupostos da HME, como o caso da teoria de fraude no mercado.

Tal teoria, doutrina legal utilizada pelo judiciário nos Estados Unidos, permite iniciar ações de fraudes nos mercados acionários sem as provas necessárias em outros tipos de ações similares. Em mercados eficientes, a teoria de fraude é uma constatação lógica. Se o preço reflete toda a informação disponível, também incorpora a informação privilegiada. Isso provocaria grandes oscilações de preços em virtude do uso desse tipo de insider information. Assim, a legislação dispensa a apresentação das provas necessárias em quaisquer outras ações contra fraude. Basta haver oscilação grande de preços. A teoria de fraude no mercado emergiu no final dos anos 70, foi recepcionada por juízes em vários casos no mercado acionário e foi endossada por uma decisão da Suprema Corte americana no caso Basic v. Levinson, em 1988. Após isso, tornou-se referência para julgamentos semelhantes.

A influência da HME no estudo econômico da lei é maior ainda em se tratando dos mercados financeiros, uma vez que tais ambientes, segundo Samuelson (1965), são mercados perfeitos porque: 1) a ação individual de um investidor particular não afeta o resultado agregado devido ao grande número de investidores; 2) todos os participantes são totalmente informados e têm igual acesso às transações; 3) os ativos negociados são homogêneos; e 4) operam na ausência de custos transacionais.

\section{2) Teoria de Agência}

A atual regulação dos mercados financeiros parte de certos pressupostos neoclássicos sobre o comportamento do mercado acionário. Com relação à propriedade de uma firma, pode-se dizer que as firmas são um nexo de contratos entre os empresários e todos aqueles que se relacionam de alguma maneira com a empresa, os chamados stakeholders (funcionários, fornecedores, governo, acionistas, etc.). Como o mundo real apresenta fricções (custos de transação) causadas por assimetrias informacionais e potencial comportamento oportunista dos agentes econômicos, esse conjunto de contratos se torna imperfeito e por isso os direitos de propriedade não são negociados a custo zero. Agentes potencialmente oportunistas operando em um ambiente como este diminuem a eficácia das transações (Williamson, 1996).

\footnotetext{
${ }^{38}$ A força que a HME ganha nos nas décadas de 70 e 80 é tão grande que vários de seus seguidores - mesmo os mais jovens - ganharam o Prêmio Nobel.
} 
É importante notar que, para os autores da teoria da agência (como Fama e Jensen, 1983a) a chamada racionalidade limitada tem influência apenas no aspecto de que é impossível desenhar (ex-ante) contratos que definam plenamente todos os eventos futuros. A partir desse problema e de outros (como a impossibilidade de monitoramento perfeito, do potencial comportamento oportunista por parte dos agentes econômicos e da emergência de assimetria informacional) surgem diversos outros que agregam custos adicionais às transações. ${ }^{39} \mathrm{~A}$ literatura de direito de propriedade resultou, do ponto de vista de análise microeconômica, na análise da chamada governança corporativa, que aborda a teoria de agência, o estudo da estrutura societária das firmas e a regulação do mercado acionário. A partir do trabalho de Berle e Means (1932), surge a discussão sobre o problema de agência (Jensen e Meckling, 1976). De acordo com essa teoria, existem contratos incompletos (imperfeitos) entre os "agentes" que tomam decisões nas firmas e o principal (sócio). Na hipótese da existência desse tipo de imperfeição contratual e de um potencial comportamento oportunista por parte do executivo (agente), pode haver transferência de riqueza dos sócios para os executivos em virtude de decisões tomadas pelos agentes.

Tais problemas surgem porque os contratos entre os agentes e principais não podem ser definidos e cobrados sem custos, que incluem estruturação e monitoramento ${ }^{40}$ de uma série de relações e conflitos de interesses. A preocupação com o problema entre o agente e o principal é antiga. Em "A Riqueza das Nações", Adam Smith já dizia que não se pode esperar que os diretores de joint-stock companies operem com a mesma vigilância dos sócios-diretores de uma empresa comum (Jensen e Meckcling, 1976). Segundo esses autores, em um mercado de capitais competitivo haveria pouco espaço para um comportamento oportunista porque os investidores estariam atentos às tomadas de decisão por parte dos executivos, e eventuais decisões "erradas" seriam punidas automaticamente e se refletiriam nos preços. Tal mercado seria especializado em formar os preços das ações e negociá-las a baixos custos.

As companhias abertas teriam características que tornariam possível o controle do problema de agência por meio do mercado de capitais porque as ações teriam seus direitos residuais irrestritos, uma vez que: 1) acionistas não teriam nenhum outro papel na organização; 2) seus direitos residuais seriam livremente alienáveis; e 3) tais direitos representariam o valor líquido do fluxo de caixa descontado da empresa (Fama e Jensen, 1983a). Como as ações podem ser vendidas a qualquer momento com baixos custos transacionais, os acionistas que percebessem que os diretores de determinada empresa estivessem tomando decisões que diminuíssem as perspectivas de geração de fluxo de caixa futuro poderiam se desfazer de seus direitos rapidamente. Nessa visão neoclássica, o preço das ações é um preciso e transparente retrato do desempenho dos diretores (Cunningham, 2002).

Assim, a ação dos investidores no mercado acionário forçaria a retirada de tais diretores sob pena de a empresa ter suas ações desvalorizadas de maneira significativa a ponto de eventualmente haver uma aquisição hostil (hostile takeover). Dessa maneira, os agentes seriam monitorados constantemente, e suas ações seriam avaliadas instantaneamente (Fama e Jensen, 1983b), o que eliminaria naturalmente os problemas de agência.

\footnotetext{
${ }^{39} \mathrm{O}$ avanço da teoria de custos de transações a partir do trabalho de Coase foi realizado por diversos autores, como Williamson. Para esta vertente, as transações são impactadas pela incerteza, pela característica dos ativos (se estes são específicos ou não) e pela recursividade (freqüência com que se dão as transações) (Williamsom, 1985 e 1996).

${ }^{40} \mathrm{O}$ problema do monitoramento é lembrado por vários autores como básico em qualquer especificação de relações complexas entre agentes econômicos, como Arrow (1991).
} 


\section{3) Behavioral Finance, Law and Economics e Regulação do}

Mercado Financeiro

Considerando-se os argumentos sobre o comportamento quase racional dos agentes nos mercados financeiros descritos nas seções anteriores, é possível admitir que, mesmo se houver controle dos problemas de agência em sua totalidade, ainda assim haveria ineficiências nos mercado de capitais provocadas pelo comportamento dos investidores (Cunnigham, 2002).

Como já foi visto anteriormente, investidores, por exemplo, têm aversão à perda (fato que inibe uma eficiente realocação do portfolio), apresentam excessiva confiança em suas habilidades em escolher ativos, são pouco céticos e não dão o devido desconto às informações prestadas por bancos, brokers, analistas, auditores e empresas que têm forte incentivo para manipulá-las mais ainda se quiserem se aproveitar da chamada reação exagerada por parte de investidores, como mostrado anteriormente. Se alguns sabem que investidores exageram suas expectativas para ações que vêm dando retornos positivos, mesmo resultados não muito bons podem ser considerados excepcionais, o que traz vantagens para aqueles que reconhecem isso (empresas, analistas e bancos de investimento, por exemplo). Da mesma maneira, analistas podem manter o viés de compra para as ações que se valorizaram recentemente sem precisar dar muitas justificativas para tanto, mantendo assim o fluxo de negociação e a carteira de clientes na corretora e/ou no banco de investimentos para quem trabalham.

Ao contrário da teoria de agência, que ainda lida com boa parte de pressupostos da teoria neoclássica - como a presunção de que os agentes têm racionalidade ilimitada e por isso tomam decisões baseados em expectativas racionais - a teoria de Finanças Comportamentais parte desse pressuposto: agentes não conseguem tomar decisões racionais a todo instante (têm problemas de vieses no processo cognitivo e limites ao aprendizado), e arbitradores racionais são limitados em seus esforços para eliminar tais distorções. De acordo com alguns autores, como Jensen e Meckling, os problemas de agência seriam controlados em mercados de capitais competitivos porque investidores seriam céticos com relação às informações divulgadas pelas empresas e puniriam aqueles gestores que tomassem decisões conflitantes com os interesses dos acionistas.

A tradicional área de pesquisa norte-americana da Economia do Direito é extremamente influenciada pela hipótese de mercados eficientes, ou seja, admite que os preços praticados nos mercados são a melhor estimativa do valor dos ativos. Se houver problemas, é possível que o mercado os resolva, como na abordagem de Jensen e Fama. De acordo com essa linha de raciocínio, se os mercados não resolverem os problemas de oportunismo, bastaria uma regulação que se concentre na tentativa de eliminar eventuais comportamentos oportunistas oriundos de assimetrias de informação, custos de transação e problemas de agência.

De acordo com Canuto e Lima (2001), mesmo em países em que os mercados financeiros são menos desenvolvidos, como os latino-americanos, a regulamentação corrente privilegia a eliminação de problemas decorrentes de ineficiências de mercado com maior transparência informacional. Disseminando informações para um mercado competitivo, como seria o de capitais, criam-se condições para que investidores, que tomam decisões baseadas em expectativas racionais, monitorem o comportamento dos executivos das empresas. Entretanto, não é de se esperar, pela teoria de Finanças Comportamentais, que investidores sejam céticos ao extremo e monitorem as atitudes dos executivos das empresas. Investidores apresentam excessiva confiança e raramente admitem que podem ter tomado decisões erradas no passado (loss aversion). 
Sob esta nova perspectiva, é plausível supor que os investidores exibam reação exagerada a notícias sobre empresas (overreaction), exacerbem padrões de curto prazo - considerando que estes são estatisticamente relevantes (representative heuristics) - e exibam aversão à perda, entre outros comportamentos não típicos de um indivíduo estritamente racional (Cunningham, 2002). Assim, um modelo sobre o comportamento do investidor típico deveria pressupor que este tende a:

1) comprometer-se com uma decisão tomada previamente, a manter as atitudes e crenças iniciais (status quo bias) para preservar a consistência com a decisão original e a apresentar excessiva confiança em suas atitudes, e por isso são demasiadamente crédulos a respeito de informações que corroboram as suas crenças (anchoring) (Hirshleifer, 2001);

2) desenvolver crenças que servem às suas opiniões iniciais, ou seja, analisam os dados a fim de torná-los coerentes com suas posições iniciais; e

3) exagerar a probabilidade de um evento recente, de grande publicidade ou traumático ${ }^{41}$.

Sendo assim, é muito possível que mesmo o competitivo mercado de capitais dos EUA não puna executivos por decisões equivocadas que estejam tomando e venham a destruir valor para os acionistas. Quando tomados por excesso de otimismo, como se verificou durante quase toda a década de 90, investidores ignoram eventuais deslizes administrativos (desonestos ou não). Este parece ser o pano de fundo de muitas demandas jurídicas que estão em voga nos EUA nesses últimos meses, desde as fraudes contábeis de grandes empresas como Enron, WorldCom e Xerox, até os suspeitos processos de ofertas públicas iniciais conduzidas nos últimos anos da década passada por bancos de investimento.

Defensores da regulação mínima dos mercados de capitais (que não vai muito além da promoção de maior disseminação de informações) citam alguns argumentos que merecem consideração, como os mecanismos criados pelo próprio mercado (as agências de classificação de risco e as empresas de auditoria independente) para funcionar como instituições de verificação da qualidade das informações disponibilizadas pelas empresas. Assim, não deveria haver regulação de como as informações deveriam ser anunciadas porque bastariam aos investidores o ceticismo com relação às informações das empresas e a confiança na reputação das instituições de auditoria e de classificação de risco. Os exemplos citados anteriormente, entretanto, não fornecem argumentos que validam a eficácia dessas instituições em analisar de maneira imparcial os dados das empresas e muito menos garantem que investidores, tomados por excesso de otimismo ou pela chamada aversão à perda, sejam céticos, como prevêem os defensores da HME (Hishlerifer, 2001).

\footnotetext{
${ }^{41} \mathrm{O}$ fato de que várias pessoas consideram que homicídios e acidentes automobilísticos são causas mais comuns de morte do que diabetes e câncer estomacal nos Estados Unidos, quando de fato o contrário é verdade em uma proporção de quase 10:1, mostra como a exposição na mídia afeta a avaliação de probabilidades das pessoas (Cunningham, 2002).
} 


\section{4) Implicações para a regulação dos mercados fianceiros}

Esta abordagem comportamental da teoria de Finanças provoca a introdução de novas estruturas regulatórias que diferem, em certo aspecto, da existente hoje, que privilegia o combate às assimetrias informacionais e aos problemas de agência. Em mercados financeiros perfeitos (pressupondo válida a HME), a intervenção governamental poderia apenas, em princípio, promover ganhos sociais, evitando a geração duplicada de informações pelos agentes (Hirshleifer, 2001). Os problemas oriundos da racionalidade limitada provocam, por exemplo, alocação ineficiente dos recursos e períodos de euforia seguidos de pânico (fatos rotineiros na história do mercado de capitais, como os já descritos) que aumentam a volatilidade dos preços. Além disso, tendências e reversões violentas de preços que provocam desvios com relação aos fundamentos não são desejáveis, mesmo se não causarem bolhas e pânicos, porque distorcem o processo de alocação de capitais e provocam sérios problemas para o desenvolvimento das economias (Cunningham, 2002).

Uma legislação que tratasse disso, ajudando investidores a fugir de erros cognitivos e promovendo uma maior eficiência na alocação dos recursos, poderia gerar benefícios que excederiam os custos intrínsecos de uma eventual regulação. Sendo assim, surgem novos fundamentos para regulação diferentes dos hoje contemplados tanto na legislação brasileira como na de outros países (Hirshleifer, 2001).

\subsection{1) Educação dos investidores}

Mais nos EUA do que no Brasil, existe grande esforço de disseminação de informações sobre regras de como operar com ações, por exemplo. Mas não existe nada que alerte investidores sobre eventuais atitudes erradas que possam cometer ao administrar suas posições (como loss aversion e overconfidence, dois fatores que certamente levam os agentes a fazer operações com excessiva alavancagem). Além disso, investidores tendem a exibir excessiva confiança em suas atitudes e ignoram fatos contrários às suas crenças preliminares, principalmente em momentos de excessivo otimismo (bolhas) ou pessimismo (pânicos). No Brasil, comparando-se com o que existe nos Estados Unidos, há muito poucas informações sobre como operar em mercados de capitais e nada sobre vieses e eventuais problemas oriundos da racionalidade limitada. Entretanto, mesmo os programas educacionais nos EUA não consideram importante alertar os investidores a respeito dos vieses cognitivos a que estão sujeitos e muito menos à potencial ação oportunista de outros agentes (emissores de ações, empresas, corretores, etc.) que percebem tais erros.

Um ponto a destacar aqui é a grande influência que existe, entre investidores de todo mundo, do jornalismo econômico especializado (jornais, sites, revistas, etc.). Certamente tais mídias influenciam os investidores de duas maneiras: 1) ao procurar razões que explicam os movimentos dos preços, ajudam a reforçar a excessiva confiança dos investidores uma vez que as explicações dos textos da imprensa sobre os acontecimentos dos mercados financeiros geralmente implicam que seria possível obter lucro com base nas notícias divulgadas, o que certamente não é verdade; e 2) as notícias divulgadas têm poder de afetar o julgamento das pessoas sobre probabilidades, como citado anteriormente, o que reforça o chamado emotional trading e como conseqüência provoca excessos de otimismo e de pessimismo que, no limite, podem levar a bolhas e pânicos. Isso ocorre porque as pessoas sofrem do chamado hindsight bias, tendência de se acreditar que era possível prever o resultado de eventos futuros com antecipação e também do chamado excesso de otimismo/confiança. 
Interessante notar que são poucos os episódios especulativos de que se têm notícia antes do aparecimento dos jornais. Os textos econômicos sobre o assunto, como o de Kindleberger (1996), destacam o primeiro episódio como o das Tulipas na Holanda em 1630, período em que aparecem os primeiros jornais na Europa. Jornalistas econômicos têm como um de seus objetivos criar manchetes que atraiam interesse dos investidores. Os vários exemplos encontrados durante a história dos episódios especulativos ${ }^{42}$ mostram que a mídia é um propagador fundamental dos movimentos exagerados de preços (bolhas e pânicos) por meio de seus esforços para atrair a atenção do público (Shiller, 1999).

Programas educacionais que alertassem sobre esse tipo de efeito e de outros potenciais vieses cognitivos certamente melhorariam a alocação dos recursos e ajudariam investidores a cometer menos erros em decisões de investimento. Cunningham (2000) propõe uma espécie de carteira de trânsito para investidores. Estes passariam por um teste em que seriam expostos aos conceitos tradicionais de finanças e também aos aspectos comportamentais que podem afetar de maneira negativa seu desempenho como investidores. Após isso, ao menos os investidores estariam conscientes, assim como o são os motoristas de trânsito, de que poderão sofrer sérios prejuízos se cometerem certos erros, como ter exagerada confiança em suas previsões ou não se desfazer de ativos ruins em virtude da chamada aversão à perda. Pesquisas futuras relacionadas a este tema podem conduzir ao desenho de uma estrutura educacional que ao menos tente disseminar entre os investidores os vieses do processo cognitivo e os limites ao aprendizado que afetam o comportamento dos investidores.

\subsection{2) Regulação da relação entre agentes do mercado e investidores}

O comportamento oportunista, neste contexto, surge da percepção, por parte de alguns agentes do mercado de capitais (notadamente emissores de securities) de que outros agentes são não-racionais. Assim, brokers reconhecem que investidores têm excessiva confiança e os estimulam a operar maciçamente ao darem descontos de corretagem para operações de day trading $^{43}$ e oferecerem operações de alavancagem como compra de ações com depósito de apenas margem do valor total (Cunningham, 2002). ${ }^{44}$ Inúmeros são os participantes do mercado que indicam um comportamento oportunista de corretores com relação a investidores (especuladores) sem muita experiência em operações nos mercados financeiros. De acordo com Tobin (1984), John Train, experiente profissional na área de investimentos, mostrou em artigo publicado no New York Times (12/5/1984) que em sua opinião os mercados financeiros acabam sendo grandes cassinos, em que os agentes vendedores desses serviços atraem clientes "amadores" para um jogo de soma negativa - como os mercados acionários e de derivativos em que os grandes ganhadores são os profissionais que operam as trocas de ações e de contratos para clientes (corretores) e os agentes que auxiliam na emissão de títulos (bancos de investimento, distribuidoras, corretoras).

\footnotetext{
${ }^{42}$ Para maiores detalhes sobre episódios especulativos e o papel da imprensa, ver Kindleberger (1996), Chancellor (1999) e Galbraith (1996, 1997). Para maiores detlahes, veja apêndices ao final deste trabalho.

${ }^{43}$ As próprias Bolsas de Valores do mundo inteiro oferecem desconto de corretagem para operações de day trading.

${ }^{44}$ Este tipo de comportamento oportunista é definido como churning (Cunningham, 2002).
} 
O fato de os mercados financeiros girarem volumes muito superiores ao aceitável do ponto de vista econômico realmente sugere que a grande maioria das transações são feitas por motivos puramente especulativos, sem motivação econômica alguma, o que caracterizaria por si só uma grande confiança entre os participantes dessas transações. Pode-se mostrar o mercado de derivativos como um bom exemplo desse tipo de excessiva confiança. Nesses mercados (em que são negociados contratos futuros, de opções, a termo e swaps), apenas de $3 \%$ a $5 \%$ dos contratos realmente são levados até o vencimento (o que caracteriza o hedge levado até o fim). Obviamente um hedger poderia se desfazer de sua posição antes, mas os relatórios das Bolsas demonstram que tais participantes detêm menos de 30\% dos contratos em aberto (posições de compra ou de venda ainda não fechadas).

Além disso, análises de bancos e corretoras estimulam o comportamento chamado de aversão à perda (loss aversion) ao fazer poucas recomendações de venda de ações quando se vivem momentos de neutralidade ou otimismo nas expectativas. Esta prática foi um dos fundamentos utilizados pela SEC contra a Merril Lynch no caso de algumas emissões (IPOs) de ações de empresas "pontocom". De acordo com Shiller (2000), essa tendência de viés nas recomendações de compra se intensificou durante a década de 90. Apenas 1\% dos relatórios desse tipo recomendava venda ao final de 1999, quando em 1989 o percentual era de $9 \% .{ }^{45}$

Nesta abordagem comportamental, surge a necessidade de que as informações sobre empresas e prospectos de venda de emissões e de fundos de investimento devem ser completas (como em tese são hoje) e principalmente salientes, pois investidores são overconfidents e tendem a ignorar riscos se estes não estiverem bem salientes. Nos EUA e mesmo no Brasil há regras com relação à necessidade de informar investidores sobre as características do que está sendo ofertado, mas não há preocupação com saliência, e muitas vezes os riscos são colocados em notas de rodapé. A overreaction, aliada aos programas de bônus mediante pagamento em opções de compra aos executivos, presumivelmente induziu ao comportamento oportunista por parte dos diretores das empresas em tentar, a qualquer custo, superar as expectativas dos analistas e assim receber compensações maiores do que receberiam em situações normais (Richardson et al, 2000).

De acordo com o jornal New York Times (23 de dezembro de 2002), as maiores corretoras de ações nos Estados Unidos concordaram em pagar US\$ 1,4 bilhão para que a promotoria encerrasse os processos em que são acusadas de distribuir a clientes recomendações com informações incorretas a fim de induzi-los a efetuar operações. A maior multa será paga pela Salomon Smith Barney, empresa do Citigroup: cerca de US\$ 325 milhões. Na seqüência, Credit Suisse First Boston (150) e Merril Lynch (100) pagarão as maiores indenizações, que serão distribuídas entre as Bolsas, órgãos regulatórios e os Estados. Segundo o professor de Direito da Universidade de Columbia, John Coffee, "We can't say there won't again be bubbles, but we've convinced investors that they cannot rely on gurus."

O fato de investidores não serem céticos o suficiente com relação às informações prestadas pelas empresas está provocando grandes mudanças tanto nos Estados Unidos e em outros países. Como acreditar em números auditados por firmas que são, além de prestadores de outros serviços como consultoria, sócias das empresas que fiscalizam?

\footnotetext{
${ }^{45}$ A comparação fica mais dramática quando se vêem os dados de pesquisa publicada na revista Business Week em 1983, ano do início do mercado de alta que durou até 2001. As de venda significavam $26,8 \% ; 48,7 \%$ eram de manutenção e apenas 24,5\% eram recomendações de compra (Shiller, 2000a).
} 
No Brasil, o Banco Central está preparando um pacote de medidas que vai estabelecer restrições nos serviços prestados às instituições financeiras pelas firmas de auditoria. As novas regras vêm no encalço dos recentes escândalos corporativos nos Estados Unidos e complementam e substituem um normativo de 1996 do BC, a Resolução 2.267, que estabeleceu o rodízio de auditoria externa a cada quatro anos. Desta vez, o objetivo do BC é evitar o possível conflito de interesses na prestação de serviços de consultoria e assessoria, além de estabelecer padrões de relacionamento entre auditor e instituições financeiras. As quatro maiores firmas mundiais de auditoria, PricewaterhouseCoopers, Deloitte Touche Tohmatsu, KPMG e Ernst \& Young, dominam, juntas, cerca de $70 \%$ do mercado de auditoria para instituições financeiras de capital aberto no Brasil.

As empresas costumam prestar outros serviços que, muitas vezes, são mais bem remunerados do que a auditoria externa. $\mathrm{O}$ caso da auditoria Arthur Andersen, que entrou em colapso depois do escândalo da empresa de energia americana Enron, disparou os alarmes de segurança nos órgãos reguladores de todo o mundo e resultou em regras mais restritivas às operações das firmas de auditorias. Em 2000, a Enron pagou US\$ 27 milhões à Andersen em honorários pelos serviços de consultoria e US\$ 25 milhões pelos trabalhos de auditoria externa. No Brasil, os bancos Nacional e Econômico foram os protagonistas dos maiores escândalos envolvendo fraudes contábeis, que vieram a público em meados da década de 90 e incluíam, no caso do Nacional, lançamento de créditos fíctícios.

\subsubsection{1) O viés inconsciente dos auditores e a provável ineficácia das leis propostas recentemente nos Estados Unidos e no Brasil}

Visando a eliminar o claro conflito de interesses entre os serviços de consultoria e auditoria, em julho de 2002 o presidente dos Estados Unidos sancionou a Lei Sarbanes-Oxley, que trata de questões relativas à responsabilidade corporativa. A norma, criada com aprovação de amplas maiorias tanto na Câmara como no Senado, cria restrições legais a executivos e dá proteção a delatores de crimes corporativos. Além disso, coloca a indústria da auditoria sob rígida fiscalização governamental e prevê vários anos de prisão para aqueles que forem pegos manipulando balanços e outras demonstrações financeiras. Neste exemplo se encontra a mesma distinção que se faz com relação às normas baseadas em aspectos comportamentais e aquelas que têm base em um comportamento racional dos agentes. Se realmente todos são racionais, então os balanços "fraudados" são provocados apenas por ações oportunistas (criminosas) por parte de executivos e auditores.

Entretanto, incorporando-se os aspectos comportamentais vistos anteriormente neste trabalho, chega-se à conclusão de que acabar com tais problemas de auditoria não parece tão simples assim. Não bastam ameaças de prisão para acabar com esses problemas, assim como não basta disponibilizar informações aos investidores e acreditar que estes vão ser suficientemente céticos para descontar eventuais comportamentos oportunistas (como as recomendações exageradas). Como apontam Bazerman et al (2002), atribuir a maioria dos erros à corrupção deliberada seria acreditar que a profissão de contador está infestada por trapaceiros, o que certamente não é verdade. Aplicando-se conceitos comportamentais, demonstra-se que auditores, assim como qualquer ser humano, estão sujeitos aos vieses no processo cognitivo e também aos limites ao aprendizado vistos anteriormente. Estreitas relações entre as firmas de auditoria e seus clientes e a natureza subjetiva de algumas regras contábeis podem induzir o mais honesto dos auditores a mascarar os resultados de determinada firma e a passar informações incorretas a investidores, organismos fiscalizadores e até mesmo aos executivos da empresa auditada. 
As raízes de tal viés inconsciente dos auditores, como o chamam Bazerman et al (2002), estão baseadas nos limites ao aprendizado, como o "ancoramento" (anchoring), tendência a se interpretarem informações de acordo com opiniões preliminares que formamos sobre determinado assunto. Temos grande tendência a analisar dados em "causa própria", inconscientemente ignorando fatos contrários às nossas opiniões e exacerbando a importância daqueles que corroboram com nossos pré-conceitos sobre determinada questão. Embora seja verdade que muitas das decisões contábeis são "preto no branco", muitas outras requerem interpretação de informações que podem ser ambíguas: o que é um investimento? O que pode ser considerado como despesa? Quando uma receita deve ser reconhecida? A interpretação de vários itens de uma demonstração financeiras raramente é óbvia.

Para se ter uma idéia disso, a revista Money anualmente envia a 50 preparadores profissionais de declarações anuais de imposto de renda dados sobre rendimentos e gastos de uma família hipotética. Em 98, a faixa de variação das respostas oscilou 83\% (US\$ 37,715 contra US\$ 68,912). Em 90, apareceu a maior distorção (976\%, US\$ 6,807 contra US\$ 73,247). Tais resultados são tão distantes porque decidir o que é renda, o que é deduzível e qual é um cronograma de depreciação apropriado não é uma tarefa simples e objetiva. Da mesma maneira, um auditor de uma empresa dificilmente encontrará uma regra clara de como alocar gastos com pesquisa e desenvolvimento (despesa ou investimento?), o que muda radicalmente os resultados demonstrados pela empresa. E as opções de compra de ações doadas a executivos: são despesas com funcionários? Mas quanto valem essas opções: se o preço das ações varia constantemente, o que imaginar sobre o preço de um direito de compra sobre essa mesma ação? Tais direitos podem valer muito, assim como podem perder totalmente seu valor se estiverem próximos de sua data de vencimento (Bazerman et al, 2002).

Outro problema que surge e que não tem nada a ver com comportamento oportunista (neste caso, corrupto) é o fato de que as pessoas tendem a avaliar determinado problema levando em consideração as opiniões de outros indivíduos que fizeram tal análise anteriormente. Isso se torna ainda mais nítido quando tal análise preliminar é coincidente com o pré-conceito que a pessoa tem sobre o problema. Por exemplo, se alguém diz que você merece um aumento salarial maior do que os fatos podem sugerir, é mais provável que você concorde com essa opinião do que se tivesse que decidir por conta própria se merece um aumento maior. Esse tipo de raciocínio implica que uma auditoria tem mais chances de aceitar a contabilidade de seu cliente, o que provavelmente não seria verdade se ela mesma a fizesse do início ao fim sem ter uma opinião preliminar.

Além disso, pode-se notar que existe determinado comportamento de aversão à perda também presente nessa análise comportamental dos auditores. Em algum momento, certamente determinados auditores perceberam que alguns vieses cognitivos estavam promovendo distorções contábeis. E agora, pode dizer determinado auditor, vamos assumir o erro? Perder reputação? Como disse Charles Niemeier, contador-chefe da divisão de fiscalização da SEC (Securities and Exchange Comission), "pessoas que nunca pretendem fazer algo errado acabam se vendo em situações nas quais são quase forçadas a continuar cometendo uma fraude uma vez que tenham começado a fazer isso. De outra maneira, será revelado que elas haviam usado contabilidade inadequada em periodos anteriores". (Bazerman et al, 2002). Estudos realizados pelos mesmos autores com auditores, jovens e experientes, mostrou que, se um auditor analisa determinado balancete sabendo que este foi feito por seu "cliente", tem $30 \%$ mais chance de aceitar que o demonstrativo está correto do que outro que foi contratado por uma empresa que pretende fazer negócios com a empresa que está tendo o balancete auditado. Se isso ocorre num relacionamento hipotético, o que poderá acontecer quando os relacionamentos são tratados em contratos de longo prazo, que prevêem milhões de dólares em receitas para as firmas de auditoria? 
As propostas da Lei Sarbanes-Oxley, considerando que nem todos são tão racionais como prevê a teoria de mercados eficientes, não parece que elimina os problemas hoje existentes nas relações entre empresas, investidores e firmas de auditoria. Uma das normas obriga os auditores a informar se há algum conflito de interesses: são obrigado a mostrar quanto ganham da empresa auditada em outros serviços (a lei permite que alguns trabalhos, exceto a auditoria, sejam prestados). Suponhamos que determinada empresa de auditoria informe que ganha US\$ 30 milhões: de quanto deveria ser o desconto que o investidor deveria dar ao ler os números das demonstrações financeiras? Parece que o ponto chave para eliminar os problemas não passa pelas propostas da Lei Sarbanes-Oxley, que em parte estão sendo adotadas pelo BC brasileiro.

É necessário eliminar os incentivos que provocam resultados negativos para investidores em virtude da existência dos vieses cognitivos e limitadores ao aprendizado que afetam a todos, inclusive auditores. Reduzir o interesse de um auditor em tornar seu cliente satisfeito pode ser uma saída. O auditor, assim como um fiscal, não pode estar preocupado com a avaliação que seu cliente irá fazer após o térmimo da auditoria. Se realmente se quiser resolver os problemas de conflito de interesses, não se pode admitir que a mesma empresa preste a uma firma outros serviços que não sejam os de auditoria. Além disso, é preciso que os auditores não tenham suas receitas vinculadas aos resultados que apresentam em suas análises. Hoje eles podem ser dispensados se uma empresa não "aprecia" seus trabalhos. Contratos limitados a um ano com valores fixos poderiam resolver isso em parte. Ao mesmo tempo, uma mesma empresa de auditoria não poderia ser recontratada (o rodízio deveria ser anual, e não quadrienal, como proposto pelo BC). Nos Estados Unidos, não existe o sistema de rotação, e o cliente continua podendo demitir seu auditor se não gostar de seu trabalho. Na atual conjuntura legal, mesmo com as novas propostas e leis já vigentes, permanecem altos os incentivos para os auditores manterem seus clientes "felizes".

\section{4) Conclusões}

Se investidores são altamente racionais, o fato de que empresas e emissores de securities podem manipular dados não deve ser uma preocupação de política regulatória de primeira ordem. Tais investidores seriam capazes de perceber tais manipulações e de descontar isso do preço dos ativos, como prevêem Fama e Jensen (1983). Entretanto, se são válidos os argumentos das Finanças Comportamentais, alguns princípios comportamentais, como overreaction, availability heuristics e anchoring, devem ser levados em consideração. Assim, informações importantes para projeções de fluxos de caixa e para avaliação do preço dos ativos deveriam ser salientadas como tais, ao mesmo tempo em que as observações secundárias deveriam não atrapalhar o processamento das outras. Pesquisas acadêmicas podem ajudar a determinar quais as informações importantes para avaliação dos preços dos ativos e quais aquelas que podem ser deixadas para as notas de rodapé (Hirshleifer, 2001).

Além disso, deveriam ser revistas as regras que regem as relações comerciais entre os agentes do mercado financeiro (corretoras, bancos de investimento), receptores de recursos (empresas e governo) e doadores (investidores individuais e institucionais). Obviamente, por sua precocidade e tendência de mudança radical à abordagem regulatória à teoria de finanças, tais sugestões apresentadas neste último capítulo estão longe de ser ideais. De fato, é difícil imaginar um sistema que elimine os problemas oriundos de vieses cognitivos e dos limites ao aprendizado. Considerar aspectos de racionalidade ilimitada e de desenho regulatório, porém, é importante não só para garantir maior proteção aos investidores contra ações oportunistas de agentes do mercado financeiro, mas também para melhorar os arranjos institucionais a fim de se preservar um mercado que é fonte crucial para o desenvolvimento de qualquer economia. 


\section{Referências bibliográficas}

AKERLOF, George A., YELLEN, Janet. 1985. "Can Small Deviations from Rationality Make Significant Differences to Economic Equilibria?”. American Economic Review, LXXV, 708-720.

ARROW, K. J. 1991. "The Economics of Agency" in Pratt,J.W. e Zeckhauser,R.J. Principal and Agents:The Structure of Business. Harvard Business School Press. Research Colloquium. pp. 241

BARBER, B. and ODEAN, T. 1998. "The common stock investment performance of individual investors.". Working paper, University of California, Davis.

BARBERIS, N. and THALER, R. 2001. "A Survey of Behavioral Finance.” University of Chicago mimeo.

BARBERIS, Nicolas, HUANG, Ming. 2001. "Mental Accounting, Loss Aversion and Individual Stock Returns". National Bureau of Economic Research, Working Paper 8190.

BAZERMAN, Max H. and NEALE, Margareth A. 1994. "Negociando racionalmente". São Paulo: Editora Atlas.

BAZERMAN, Max H., LOEWENSTEIN, George e MOORE, Don A. 2002. "Bons contadores, más auditorias: veja por quê". Harvard Business Review, novembro, vol 80, n.11, 73-79.

BECKER, G. 1976. "The Economic Approach to Human Behavior," (University of Cambridge Press), pp. 3-14.

BENARTZI, Shlomo, and THALER, Richard. 1998."Naive Diversification Strategies in Retirement Saving Plans.” American Economic Review 91(1): 79-98.

BENARTZI, Shlomo. 2001. "Excessive Extrapolation and the Allocation of 401(k) Accounts to Company Stock?" Journal of Finance 56: 1747-1764.

BERLE, A and MEANS, G. 1932. "The Modern Corporation and Private Property". New York, MacMillan.

BERNSTEIN, Peter. 1997. "Against the Gods".

BLACK, Fisher. 1986. "Noise”. Journal of Finance, 41, 529-.

CAMERER, C.F. 1998. "Bounded Rationality in Individual Decision Making". Experimental Economics, 1, 163-183.

CANUTO, Otaviano e LIMA, Gilberto T. (2001) "Regulação Bancária no Mercosul”, in Baumann (Org.), Mercosul: Avanços e Desafios da Integração, IPEA/CEPAL, Brasília.

CHANCELLOR, Edward. 1999. "Salve-se Quem Puder: Uma História da Especulação Financeira ". Companhia das Letras, São Paulo.

CHEUNG, Yin-Wong, CHINN, Menzie D. 1999. "Macroeconomic Implications of the Beliefs and Behavior of Foreign Exchange Traders?". National Bureau of Economic Research, Working Paper 7417. 
CHEUNG, Yin-Wong, CHINN, Menzie D., MARSH, Ian W. 2000. "How Do UK-Based Foreign Exchange Dealers Think their Market Operates?". National Bureau of Economic Research, Working Paper 7524.

Clotfelter, C. T., and P. J. Cook, 1993, The 'gambler's fallacy' in lottery play, Management Science 39, $93\{95$.

COASE, R. 1937. “The Nature of Firm”. Economica, 4 (Nov), p. 386-405.

COASE, R. 1954. "The Problem of Social Cost". In The Firm the Market and the Law. The University of Chicago Press.

CONLISK, John. 1996. "Why Bounded Rationality?”. Journal of Economic Literature, XXXIV (June), 669-700.

CONSTANTINIDES, George M. 1983. "Capital market equilibrium with personal tax". Econometrica, 51. May, 611-636.

CONSTANTINIDES, George M. 1984. "Optimal stock trading with personal taxes: implications for prices and the abnormal January returns". Journal of Financial Economics, March, 13, 65-89.

COOPER, M., DIMITYROV, O. and RAU, P. 2000. A rose.com by any other name, Journal of Finance.

COSTA Jr., Newton C.A. da Costa. 1990. "Sazonalidades do Ibovespa". Revista de Administração de Empresas, jul-set, 30 (3), 79-84.

COSTA Jr., Newton C.A. da Costa. 1994. "Overreaction in the Brazilian Stock Market”. Journal of Banking and Finance, 18, 633-642.

COSTA Jr., Newton C.A., LEAL, Ricardo P.C., LEMGRUBER, Eduardo F. (Organizadores). 2001. "Mercado de Capitais: Análise Empírica no Brasil”, Atlas, São Paulo.

CUNNIGHAM, Lawrence. 1994. "From Random Walk to Chaotic Crashes: the Linear Genealogy of the Efficient Capital Market Hypothesis". Washington Lee Law Review, 62, 1133-

CUNNIGHAM, Lawrence. 2002. "Behavioral Finance and Investor Governance". Washington Lee Law Review, ainda não publicado.

CUTLETR, POTERBA, J. and SUMMERS, L. Speculative dynamics. Review of Economic Studies, 58, 529-546.

DALL'AGNOL Ivana. 2002. "Retornos anormnais e estratégias reversas.” Dissertação de mestrado. EPGE/FGV-RJ.

DANIEL, Kent, HIRSHLEIFER, David \& TEOH, Siew H. 2001. Investor Psychology in Capital Markets: evidence and policy implications. Working Paper, Ohio State University.

De BONDT, Werner, THALER, Richard. 1985. "Does the Stock Market Overreact?". Journal of Finance, XI (3), July, 793-808.

De LONG, J.B., SHLEIFER, Andrei. SUMMERS, L., WALDMAN, R. 1990. "Noise Trader Risk in Financial Markets”. Journal of Political Economy, 98, 703-738.

EGGERTSSON, T. 1990. "Economic Behavior and Institutions". Cambridge Surveys of Economic Literature. Cambridge, Cambridge University Press.

EICHENGREEN, Barry. "A Globalização do Capital: Uma História do Sistema Monetário Internacional”. Editora 34, São Paulo. 
EINCHEENGREEN, Barry. 2000. “Globalização do Capital”. São Paulo, Editora 34.

ESTRADA, J. 2001. "Law and Behavioral Economics". Artigo apresentado no Encontro do Latin American Law and Economics Association em Santiago, Chile.

FAMA e FRENCH (1986) Common factors in the serial correlation of stock returns. Working paper, Graduate School of Business, University of Chicago, October.

FAMA, E. 1970. "Efficient Capital Markets: A Review of Theory and Empirical Work". Journal of Finance, 25, 383.

FAMA, E. 1980. "Agency Problems and the Theory of the Firm". Journal of Political Economy, 88, 2, 288-307.

FAMA, E. 1991. "Efficient Capital Markets II". Journal of Finance, December, 46, 5: 1575-1617.

FAMA, E. and JENSEN M. 1983a. "Separation of Ownership and Control". Journal of Law and Economics, 26, June, 301-325.

FAMA, E. and JENSEN M. 1983b. "Agency Problems and Residual Claims". Journal of Law and Economics, 26, June, 327-349.

FAMA, Eugene. 1984. "Forward and Spot Exchange Rates". Journal of Monetary Economics, XIV, 319-338.

FERRIS, S. P., HAUGEN, R.A., MAKHIJA, D. 1988. "Predicting Contemporary Volume with Historic Volume at Differential Price Levels: Evidence Supporting the Disposition Effect,", Journal of Finance, 43(3): 677-697.

FESTINGER, L. 1957. “A theory of cognitive dissonance”. Stanford: Stanford University Press.

FRANCO, Gustavo H. B. 1983. "Reforma Monetária e Instabilidade durante a Transição Republicana”. Banco Nacional de Desenvolvimento Econômico, Rio de Janeiro.

FRANKEL, Jeffrey A., FROOT, Kenneth A. 1989. "Forward Discount Bias: Is it an Exchange Risk Premium?". Quarterly Economic Review, February in Thaler (Org.) Advances in Behavioral Finance, p. 359-381.

FRANKEL, Jeffrey A., FROOT, Kenneth A. 1990. "Chartists, Fundamentalists, and Trading in the Foreign Exchange Market". The Rationality of the Foreign Exchange Market. AEA Papers and Proceedings. American Economic Review, May, 181-185.

FRENCH, Kenneth R. 1980. "Stock Returns and the Weekend Effect". Journal of Financial Economics, 8, 55-69.

FRIEDMAN, M. 1953. "The Metodology of Positive Economics". In Essays in Positive Economics, 3, 14-16.

FROOT, K. and PEROLD, A. 1996. "Global Equity Markets: The case of Royal Dutch and Shell". Case N9-296-077. Boston: Harvard Business School. New York.

GALBRAITH, John K. 1993. “A Short History of Financial Euphoria”. Makron Books,

GALBRAITH, John K. 1994. "Uma Viagem pelo Tempo Econômico”. Editora Pioneira, São Paulo.

GALBRAITH, John K. 1997. “The Great Crash 1929”. Mariner Book, New York. 

York.

GALBRAITH, K. 1996. “The Short Story of Financial Euphoria”. Makron Books, New

GALBRAITH. 1997. “The Great Crash 1929”. Mariner Book, New York.

GARBER, P. 1990. "Famous First Bubbles," Journal of Economic Perspectives, 42(2): $35-54$.

GENEAKOPLOS, J. 1992. "Commom Knowledge" Journal of Economic Perspectives, 6(4): 53-82.

GIBBONS, Michael R. e HESS, Patrick. 1981. "Day of the Week Effects and Asset Returns". Journal of Business, 54, 4, 579-596.

GIBSON, G.R. 1889. “The stock markets of London, Paris and New York”. New York: G.P. Putnam's Sons.

GREENE, William. 2000. "Econometric Analysis”. Fourth Edition, Prentice-Hall.

HALFELD, Mauro. 2001. "Finanças Comportamentais". Revista de Administração de Empresas (RAE), Abr/Jun, v.41, n.2, 64-71.

HALTIWANGER, J., WALDMAN, M. 1985. "Rational Expectations and the Limits of Rationality”. American Economic Review, LXXV, 326-340.

HIRSHLEIFER, David. 2001. "Investor Psychology and Asset Pricing”, Journal of Finance 56(4) August, 1533-1598.

HOVENKAMP, H. 1995. "Law and Economics in the United States: a brief historical survey”. Cambridge Journal of Economics, 19, 331-352.

JAFFE, Jeffrey e WESTERFIELD, Randolph. 1985. "The Weekend Effect in Commom Stock Returns: The International Evidence”. Journal of Finance, XL, 2, Junho, 433-454.

JENSEN M. and MECKLING, W. 1976. "Theory of the Firm: Managerial Behavior, Agency Costs and Ownership Structure". Journal of Financial Economics, 3, October, 305-360.

JOLLS, Christine, SUSTEIN, Cass R., THALER, Richard.. 1998. "Behaviroal Approach to Law and Economics". Stanford Law Review, 50, 1471-1550.

JOSEPHS, R., LARRICK, R.P., STEELE, C.M., NISBETT, R.E. 1996. "Protecting the self from the Negative Consequences of Risky Decisions". Journal of Personality ans Social Psychology, 62, 26-37.

KAHNEMAN, Daniel, TVERSKY, Amos. 1979. "Prospect Theory: An Analysis of Decision Under Risk”. Econometrica, March, V.47, n.2, 263-291. Publishing.

KATONA, George. 1975. "Psychological Economics". Amsterdam: Elsevier Scientific

KENNEDY, Peter. 1997. "A Guide to Econometrics". The MIT Press, Cambridge, Massachussets.

KEYNES 1936

KINDLEBERGER, Charles P. 1996. "Manias, Panics, and Crashes. A History of Financial Crises". New York, John Wiler \& Sons, Inc.

LA PORTA, R., LAKONISHOK, SHLEIFER and VISHNY. Good new for value stocks: Further evidence on market efficiency. Journal of Finance, 52, 2073-2090. 
LAFFONT, J-J e MELEU, M. 2001. "Separation of Powers and Development”. Journal of Development Economics, 64, p. 129-145.

LAKONISHOK, Josef \& SMIDT, Seymor (1986). Volume for winners and losers: taxation and other motives for stock trading. Journal of Finance, XLI, 4, Sep, 951-974.

LAKONISHOK, SHLEIFER, VISHNY, 1993. Contrary investment, extrapolation and risk. NBER Working paper XXXX.

LEIBENSTEIN, H. 1996. “Allocative Efficiency vs. X-Efficiency”. American Economic Review, (June), 56 (3).

LEMGRUBER, Eduardo Facó, BECKER, João Luiz e CHAVES, Tânia Barbosa da Silva. 2000. "O Efeito Fim de Semana no Comportamento dos Retornos Diários de Índices de Ações". in Costa Jr, Leal e Lemgruber (Org.) Mercado de Capitais: Análise Empírica no Brasil, p. 143-151. Rio de Janeiro, COPPEAD-UFRJ, Editora Atlas.

LÉRIAS, Reinéro Antônio. 1988. "O Encilhamento e da cidade de São Paulo". Monografia de Mestrado apresentada à Faculdade de Filosofia, Letras e Ciências Humanas da Universidade de São Paulo. São Paulo.

LEVINE, Ross. 1997. "Financial Development and Economic Growth: Views and Agenda". Journal of Economic Literature, Vol.XXXV (June), 688-726.

LOBO, Eulália M. L. 1976. "O Encilhamento". Revista Brasileira de Mercado de Capitais, 2(5), 261-301.

MACKAY, Charles e De la VEGA, Joseph. 1996. "Extraordinary Popular Delusions and the Madness of Crowds \& Confusión de Confusiones ". John Wiley \& Sons, Inc, New York.

MAS-COLELL, Andreu, WHINSTON, Michael D., GREEN, Jerry R. 1995. "Microeconomic Theory". Oxford University Press.

MILANEZ, Daniel Yabe 2001b. "Efeito Dia da Semana no Mercado Acionário Brasileiro". (Trabalho elaborado para a disciplina "Econometria I", 1o semestre/2001), IPE/USP. Artigo não publicado.

MILANEZ, Daniel Yabe 2001c. "Foi o Encilhamento um Episódio Especulativo?". (Trabalho elaborado para a disciplina "História Econômica", 20 semestre/2001), IPE/USP. Artigo não publicado.

MILANEZ, Daniel Yabe. 2001a. "Economia e Finanças Comportamentais: Aplicações à Macroeconomia". (Trabalho elaborado para a disciplina "Macroeconomia", 10 semestre/2001), IPE/USP. Artigo não publicado.

MISHKIN, Frederic S.. 2000. "Moedas, Bancos e Mercados Financeiros”. LTC Editora.

MODIGLIANI, Franco, COHN, Richard A. 1979. "Inflation, Rational Valuation and the Market”. Financial Analyst Journal, March-April, 24-44.

MUTH, John. 1961. "Rational Expectations and the Theory of Price Movements". Econometrica, 29, 315-335.

NIEDERHOFFER, Victor. 1971. "The Analysis of World Events and Stock Prices". Journal of Business, 44, p:193-219.

NORTH, D. 1990. "Institutions, Insitutional Change and Economic Performance". Cambridge, Press Syndicate of the University of Cambridge. 
ODEAN, T. 1998. "Are investors reluctant to realize their losses?". Journal of Finance, $53,1775-1798$.

OSTROM, E. 1986. “An Agenda for the Study of Institutions”. Public Choice, 48 (1), pp. $3-25$.

RABIN, Matthew e SCHRAG 1997. "First impressions matter: a model of confirmatory bias". Working paper $\mathrm{n}^{\circ}$ 97-250, U. California at Berkekley.

RABIN, Matthew. 1998. "Psychology and Economics". Journal of Economic Literature, XXXVI, March, 11-46.

RASHES, M. 2001. Massively confused investors making conspicuously ignorant choices. Journal of Finance.

RICHARDSON, S, TEOH, S. and WYSOCKI, D. 2000. "The Walkdown to Beatable Analyst Forecasts: The Roles of Equity Issuance and Insider Trading Incentives" Ohio State University Fisher College of Business Working Paper.

ROBERTS, H.V. 1967. "Statistical versus clinical prediction of the stock market", unpublished paper presented to the Seminar on the analysis of security prices, University of Chicago.

ROLL, Richard. (1984). "The Orange Juice and the Weather". American Economic Review, 74, 861-880.

ROLL, Richard. (1986). "The hubris hypothesis of corporate takeovers". Journal of Business, 59, April, 197-216.

ROMER, David. 1996. “Advanced Macroeconomics”. McGraw-Hill.

ROSENTHAL, L., and YOUNG, C. The seemingly anomalous proce behavior of royal dutch shell and unilever nv/plc. Journal of Financial Economics, 26, 123-141.

RUSSEL, T., THALER, Richard. 1985. "The Relevance of Quasi Rationality in Competitive Markets". American Economic Review, LXXV, in Thaler (Org.), Quasi Rational Economics, p. 239-257.

SAMUELSON, Paul. 1965. "Proof that Properly Anticipated Prices Fluctuate Ramdomly" Industrial Management Review, 6, 41.

SAVAGE, L. J. 1954. "The sure-thing principle". In SAVAGE, L., The Foundations of Statistics. New York: John Wiley.

SHAFIR, Eldar, DIAMOND, Peter, e TVERSKY, Amos. 1997. "Money Illusion". Quarterly Journal of Economics, Vol. CXII, May, 2.

SHEFRIN, H., STATMAN M. 1985. "The Disposition to Sell Winners Too Early and Ride Losers Too Long," Journal of Finance, 40: 777-790.

SHEFRIN, H., STATMAN M. 1994. "Explaining investor preferences for cash dividends. Journal of Financial Economics.

SHEFRIN, Hersh. 2000. "Beyond Greed and Fear: Understanding Behavioral Finance and the Psychology of Investing". Harvard Business School Press.

SHILLER 1999. "Human Behavior and the Efficiency of the Financial System". In J. Taylo, and M. Woodford, ed: Handbook of Macroeconomics. Amsterdam, Elsevier.

SHILLER, Robert. 1999. "Human Behavior and the Efficiency of the Financial System". in J. Taylor, and M. Woodford, ed. Handbook of Macroeconomics, Elsevier, Amsterdam. 
SHILLER, Robert. 2000a “Exuberância Irracional”. Makron Books, São Paulo.

SHILLER, Robert. 2000b "Conversation, information, and herd behavior" American Economic Review 85, 181-185.

SHILLER. 1981. Do stock prices move too much to be justified by subsequent changes in dividends? American Economic Review, v.71, n.3, June , p.421-436.

SHIRLEY, Mary. 1997. "Pressing Issues for Institutional Economics". Paper present at the Inaugural Conference of the International Society for the New Institutional Economics. Saint Louis, September.

SHLEIFER, Andrei, VISHNY, Robert W. 1995. "The Limits of Arbitrage". National Bureau of Economic Research, Working Paper 5167.

SHLEIFER, Andrei. 2001. "Inefficient Markets: An Introduction to Behavioral Finance". Oxford University Press Inc., New York.

SHLEIFER, Andrey. 1987. "The Economic Consequences of Noise Traders". National Bureau of Economic Research, Working Paper 2395.

SIMON, Herbert A. 1976. "From Substantive to Procedural Rationality". in Simon, Models of Bounded Rationality, MIT Press, Boston.

SLOVIC, Paul, FISCHOFF, Baruch, LICHTENSTEIN, Sarah. 1979. "Rating the risks". Environment, 21, 3: 61-74.

SOLOW, Robert M. 1979. "Another Possible Source of Wage Stickness". Journal of Macroeconomics, I, 9-82.

STIGLER, George J. 1992. "Law or Economics?" Journal of Law and Economics, 25, October, 455-467.

STIGLITZ, Joseph E. 1998. "Más Instrumentos y Metas Más Amplias para el Desarollo. Hacia el Consenso Post-Washington”. Instituciones y Desarollo. (Outubre).

STIGLITZ, Joseph. 2000. "The Contributions of the Economics of Information to Twentieth Century Economics" Quarterly Journal of Economics. November, 1441-1478.

TANNURI, Luiz Antonio. 1980. “O Encilhamento”. Fundação de Desenvolvimento da UNICAMP, Campinas.

TAUNAY, Afonso de E. 1971. "O Encilhamento: cenas contemporâneas da Bolsa do Rio de Janeiro em 1890, 1891 e 1892”. Editora Itatiaia, Belo Horizonte.

THALER, R. 1992. The winner's curse: paradoxes and anomalies of economic life. New York: Free Press.

THALER, Richard 1999. "The End of Behavioral Finance". Financial Analyst Journal, Nov/Dec, 12-17.

THALER, Richard Editor. 1994. “Quasi Rational Economics”. Russel Sage Foundation..

THALER, Richard H. 1987. "Anomalies: Seasonal Movements in Securities Prices II: Weekend, Holiday, Turn of the Month and Intraday Effects". Journal of Economic Perspectives, v.1, n.1, Fall, 169-177.

THALER, Richard H. 1999. "The End of Behavioral Finance". Financial Analyst Journal, Nov/Dec, 12-17. 
THALER, Richard H. Editor. 1993. "Advances in Behavioral Finance”. Russel Sage Foundation..

THALER, Richard H., MULLAINATHAN, Sendhil. 2000. "Behavioral Economics". National Bureau of Economic Research, Working Paper 7948.

THALER, Richard. 1980. Toward a positive theory of consumer choice. Journal of Economic Behavior and Organization, 1, 39-60.

THALER, Richard. 1985. Mental accounting and consumer choice. In Thaler (Org.), Quasi Rational Economics, p. 25-48.

THALER, Richard. 1987. The psychology of choice and the assumptions of economics. In Thaler (Org.), Quasi Rational Economics, p. 137-166.

TOBIN, James. 1984. On the Efficiency of the Financial System. Lloyds Bank Review, July.

TRINNER, Gail D. 2001. "International Capital and the Brazilian Encilhamento, 18891892: An Early Example of Contagion among Emerging Capital Markets?”. Presented to Economic History Association Conference, Philadelphia, September. Trabalho não publicado.

TVEDE, Lars. 2000. The Psychology of Finance. John Willey and Sons, LTD.

TVERSKY, A. and KAHNEMAN, D. 1974. Judgment under uncertainty: heuristics and biases. Science, 185, 1124-1131.

TVERSKY, A. and KAHNEMAN, D. 1981. The framing of decisions and the psychology of choice. In WRIGHT, G. Behavioral Decision Making, Plenum Press, 1985.

WILlIAMSOM, O. E. 1985. The Economic Institutions of Capitalism. New York, Free Press.

WILLIAMSOM, O. E. 1996. The Mecanisms of Governance. Oxford University Press. 


\begin{tabular}{|c|c|c|}
\hline Período & Fundamentos da "nova era" & $\begin{array}{c}\text { Pensamento econômico da "nova } \\
\text { era" }\end{array}$ \\
\hline 1901-1907 & $\begin{array}{l}\text { Primeiras comunicações por rádio entre continentes. } \\
\text { Novas tecnologias (eletricidade). } \\
\text { Formação da US Steel e outras fusões, com vultosos } \\
\text { empréstimos bancários. }\end{array}$ & $\begin{array}{l}\text { Previsões que em breve haveria } \\
\text { comunicações por rádio com Marte } \\
\text { (Boston Post, } 1^{\circ} \text { de jan - 1901). } \\
\text { Presença de uma "comunidade de } \\
\text { interesses", segunda a qual haveria } \\
\text { tolerância à formação de grandes grupos } \\
\text { econômicos (apesar do Sherman } \\
\text { Antitrust Act). (New York Daily } \\
\text { Tribune, editorial de abril de 1901). }\end{array}$ \\
\hline 1920-1929 & $\begin{array}{l}\text { Automóveis ( } 1941 \text { - produção de } 1,7 \text { milhões; } 1920 \text { - } \\
8,1 \text { mi e } 1929 \text { - } 23,1 \text { mi). } \\
\text { Extensão do fornecimento de energia elétrica para fora } \\
\text { dos grandes centros urbanos. } \\
\text { Grande crescimento estações de rádio (meio de } \\
\text { entretenimento nacional). } \\
\text { Grande movimento de fusões e aquisições. } \\
\text { Lançamento de cotas de fundos de investimento para } \\
\text { serem negociadas em Bolsa (Closed end funds). }\end{array}$ & $\begin{array}{l}\text { "De fato uma nova era está se iniciando } \\
\text { em todo o mundo civilizado" (John } \\
\text { Moody, chefe do Moody’s Investors } \\
\text { Service, agência de classificação de } \\
\text { riscos). } \\
\text { "O mercado de ações atingiu o que } \\
\text { parece ser um patamar elevado } \\
\text { permanentemente" (Irving Fisher, de } \\
\text { Yale, um dos economistas mais } \\
\text { importantes na época, algumas semanas } \\
\text { antes do crash de outubro de } 29 \text { ). }\end{array}$ \\
\hline $\begin{array}{l}\text { Década de } \\
1950\end{array}$ & $\begin{array}{l}\text { Disseminação da televisão (em 1955, } 76 \% \text { das famílias } \\
\text { possuíam aparelhos). } \\
\text { Expansão demográfica do pós-guerra (baby boom). }\end{array}$ & $\begin{array}{l}\text { "Há uma nova atitude dos negócios em } \\
\text { si que promete evitar profundas } \\
\text { depressões no futuro." (US News and } \\
\text { World Report, 20-mai-1955). } \\
\text { "Revolução nos gastos dos } \\
\text { consumidores". Editorial de Newsweek, } \\
\text { 12-dez-1955. }\end{array}$ \\
\hline $\begin{array}{l}\text { Década de } \\
60\end{array}$ & $\begin{array}{l}\text { Eleição de John Kennedy. } \\
\text { Aproximação dos } 1000 \text { pontos do índice Dow Jones. Tal } \\
\text { marco, porém, só viria a ser ultrapassado muito tempo } \\
\text { depois, em 1982. Considerando os preços em termos } \\
\text { reais, só viria a superar o pico de } 1966 \text { em } 1992 .\end{array}$ & $\begin{array}{l}\text { "O país está entrando em uma nova } \\
\text { economia"... "os negócios podem gozar } \\
\text { de prosperidade contínua, } \\
\text { indefinidamente" (Harvard Business } \\
\text { Review, 1967). } \\
\text { "... o marco mágico de } 1000 \text { pontos do } \\
\text { índice Dow Jones será ultrapassado mais } \\
\text { cedo ou mais tarde". (Business Week, } \\
\text { 23-jan-1965). }\end{array}$ \\
\hline $\begin{array}{l}\text { Década de } \\
90\end{array}$ & $\begin{array}{l}\text { Revolução na tecnologia da informação (Internet). } \\
\text { Ligação de suposta vitória sobre rivais econômicos como } \\
\text { Europa e Japão. } \\
\text { Geração do pós-guerra (consumismo, baby boom). } \\
\text { Número altíssimo de pessoas entre } 35-55 \text { anos. } \\
\text { Expansão dos fundos de pensão, dos planos de } \\
\text { aposentadoria que investem em ações e da própria } \\
\text { indústria de fundos de investimento. } \\
\text { Aumento das oportunidades de jogos a dinheiro. }\end{array}$ & $\begin{array}{l}\text { Slogans da Merril Lynch nos anos } 90: \\
\text { "Esperamos altas nos preços das ações } \\
\text { nos EUA". Slogans comuns na década } \\
\text { de } 20: \text { "Seja um investidor otimista nos } \\
\text { EUA" "Nunca venda a descoberto nos } \\
\text { EUA". } \\
\text { Várias obras que prevêem que o } \\
\text { mercado deve crescer ininterruptamente } \\
\text { até cerca de } 2010 \text {, quando o número de } \\
\text { pessoas na faixa etária de } 45 \text { anos deve } \\
\text { começar a diminuir. } \\
\text { Em } 1998 \text {, havia } 6,2 \text { milhões de contas } \\
\text { em fundos mútuos de investimento nos } \\
\text { EUA, cerca de duas contas por família. }\end{array}$ \\
\hline
\end{tabular}

Fonte: Shiller (2000a) 


\section{APENDICE B: O Encilhamento como primeiro episódio especulativo brasileiro}

Apesar de ter havido a formação de certos setores industriais no período que dura entre meados da década de 1880 e o início da década de 1890 no Brasil, não se pode negar tanto a existência de um movimento eufórico com a presença de comportamentos "exagerados" e não racionais por boa parte dos investidores como também a atitude de extrema alavancagem, facilitada pelas regras expansionistas do Governo, representada principalmente pelo sistema bancário. ${ }^{46}$ Ao final da década de 1880 há um cenário de novas condições econômicas (transformações provocadas pela expansão do mercado de café e do mercado de trabalho, expansão da atividade industrial e um estado extremamente favorável do fluxo de capitais internacional).

Ao mesmo tempo, pelos relatos de Tannuri (1980), Franco (1983) e Taunay (1970), pode-se dizer que nesses anos o sentimento era de extrema euforia, em que certamente os agentes, influenciados por fatores psicológicos, tomaram decisões que não estão de acordo com o pressuposto neoclássico de expectativas racionais. A excessiva alavancagem, caracterizada pela facilidade de emissão de papel moeda e pela captação de recursos no mercado acionário, também é um ponto central em qualquer análise que se faça sobre o período que compreende o final do Império e o começo da era republicana brasileira. Finalmente, o pânico, provavelmente provocado pela crise de liquidez motivada pela queda de confiança de investidores estrangeiros com relação a países que praticam políticas econômicas pouco ortodoxas após a crise da Argentina em 1890, provoca rápida desvalorização dos preços dos ativos no início de 1891, principalmente as ações listadas na Bolsa de Valores do Rio de Janeiro.

Com afirma Franco (1983), o período compreendido entre 1815 e 1913 é recheado de pânicos e desastres financeiros em vários países ao redor do mundo e o Brasil não constitui uma exceção nesse cenário. ${ }^{47}$ Apesar de muitas dessas crises estarem vinculadas a ciclos econômicos ${ }^{48}$, não parecem explicar a crise do Encilhamento, uma vez que não se pode dizer que 1891 tenha marcado o fim de um ciclo do mercado cafeeiro, que sem sombra de dúvida era o mais importante para a economia brasileira à época. De acordo com Franco (1983), Hicks entende que, ao mesmo tempo em que há grandes benefícios com o crescimento do mercado financeiro, existe o problema de que esse sistema é por natureza instável. Ele repousa "em confiança e segurança". Aliás, o próprio Hicks afirma que, "quando há confiança demais ou otimismo, pode-se arrebentar em explosões de especulação". Assim, parece possível afirmar que, em alguma medida, o Encilhamento contém todas as características de outros episódios especulativos, como os descritos por Kindleberger (1996) e Galbraith (1993).

A seguir passagem bastante ilustrativa do período de excessiva euforia que se vivia na economia brasileira à época: Em 25/7/1889, passados dois dias da abertura da subscrição das ações do Banco Construtor, podia-se ler nas páginas do Jornal do Commercio: "Continua a procura por ações ..., e se foi grande o número de pessoas que concorreram ontem ao Banco de Crédito Rural, onde se fazia a subscrição, muito maior havia sido na véspera." "A sofreguidão era tamanha que os estavam na área e nas escadas, desanimados de poderem chegar na sala de inscrição, ativaram dali mesmo, dentro de sobrecartas, as quantias correspondentes às ações que desejavam obter. Aos incorporadores foi concedida no ato da organização do banco, a bonificação de 600 contos de réis, pelos serviços prestados." (Tannuri, 1980). A própria definição de Encilhamento, ligada à apostas em corridas de cavalo no Jockey, de acordo com Taunay, dá o tom do momento que se vivia. "Era o Encilhamento, palavra quase genial do povo, adaptada da linguagem característica do esporte local em que se dá a última demão aos cavalos de corrida antes de atirá-los à raia da concorrência e forçá-los, ofegantes e em supremos esforços, a pleitearem o prêmio da vitória." (Taunay, 1971).

\footnotetext{
${ }^{46}$ Essa seção se baseou em Milanez (2001c).

${ }^{47}$ Há registros de pelo menos mais seis crises financeiras sérias no século XIX: 1827, 1857, 1864, 1875, 1891 e 1900 (Franco, 1983).

${ }^{48}$ As crises de 1857, 1864 e 1875 se originaram, de acordo com Lobo (1976), com o declínio no preço do café no mercado internacional.
} 